FERNANDA VICIONI MARQUES

PROPRIEdAdES Físico-QuímicAs E CITOTOXICIDAdE

De MATERIAIS ObTURAdores De CANAIS

RAdiculares DE DENTES PERMANENTES

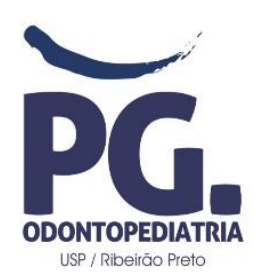

Ribeirão Preto

2018 



\section{PROPRIEDADES FÍSICO-QUÍMICAS E CITOTOXICIDADE DE MATERIAIS OBTURADORES DE CANAIS RADICULARES DE DENTES PERMANENTES}

Dissertação apresentada à Faculdade de Odontologia de Ribeirão Preto da Universidade de São Paulo, para a obtenção do Grau de Mestre em Ciências.

Área de Concentração: Odontopediatria

Orientador: Prof. Dr. Fabrício Kitazono de Carvalho

\section{Ribeirão Preto}

2018 
AUTORIZO A REPRODUÇÃO E DIVULGAÇÃO TOTAL OU PARCIAL DESTE

TRABALHO, POR QUALQUER MEIO CONVENCIONAL OU ELETRÔNICO, PARA FINS

DE ESTUDO E PESQUISA, DESDE QUE CITADA A FONTE.

\section{FICHA CATALOGRÁFICA}

Vicioni-Marques, Fernanda

Propriedades físico-químicas e citotoxicidade de materiais obturadores de canais radiculares de dentes permanentes.

Vicioni-Marques, Fernanda, Ribeirão Preto, 2018.

94 p.: il. ; $30 \mathrm{~cm}$

Dissertação de Mestrado apresentada à Faculdade de Odontologia de Ribeirão Preto da Universidade de São Paulo. Área de concentração: Odontopediatria.

Orientador: Carvalho, Fabrício Kitazono de

1. Endodontia. 2. Citotoxicidade. 3. Obturação do canal radicular. 4. Análises físico-químicas. 5. Materiais obturadores do canal radicular. 


\section{FOLHA DE APROVAÇÃO}

VICIONI-MARQUES, F. Propriedades físico-químicas e citotoxicidade de materiais obturadores de canais radiculares de dentes permanentes.

Dissertação apresentada à Faculdade de Odontologia de Ribeirão Preto da Universidade de São Paulo, para a obtenção do Grau de Mestre em Ciências. Área de Concentração: Odontopediatria

Aprovado em:

\section{BANCA EXAMINADORA}

Prof. Dr.

Instituição:

Julgamento: Assinatura:

Prof. Dr.

Instituição:

Julgamento: Assinatura:

Prof. Dr.

Instituição:

Julgamento: Assinatura:

Prof. Dr.

Instituição:

Julgamento: Assinatura: 



\section{DADOS CURRICULARES}

\section{FERNANDA VICIONI MARQUES}

Nascimento 04 de novembro de 1990, São Bernardo do Campo, SP

Filiação Feliciano Rosa Marques

Albina Aparecida Vicioni Marques

2011-2015 Graduação em Odontologia

Faculdade de Odontologia de Ribeirão Preto da Universidade de São Paulo.

Iniciação científica: "Biossegurança: controle da contaminação da água de equipos odontológicos".

Orientador: Prof. Dr. Evandro Watanabe.

Bolsa: CNPq.

2016-2018 Mestrado em Ciências

Área de Concentração: Odontopediatria

Faculdade de Odontologia de Ribeirão Preto da Universidade de São

Paulo

Dissertação: "Propriedades físico-químicas e citotoxicidade de materiais obturadores de canais radiculares de dentes permanentes".

Orientador: Prof. Dr. Fabrício Kitazono de Carvalho.

Bolsa: CAPES.

2017-2019 Curso de Especialização em Odontopediatria (em andamento).

Fundação Odontológica de Ribeirão Preto, Faculdade de Odontologia de Ribeirão Preto da Universidade de São Paulo. 

"Peça a Deus que alençae seus planas e eles darãa certa."

Pravérlias 16:3 



\section{Dedicatária}

Dedico este trabalho, bem como todas as oportunidades de estudo que tive até então à Deus, por sempre iluminar meu caminho;

Aos meus pais Albina e Feliciano, que com muito esforço e dedicação desde sempre me concederam explorar o incrível mundo da Educação, e com todo carinho e amor me ajudam a trilhar o caminho da Vida;

Ao meu namorado Guilherme, que com muita compreensão me acolhe nos momentos difíceis e comemora comigo os momentos bons. 



\section{Agradecimentas}

À Universidade de São Paulo, na pessoa do atual reitor Prof. Dr. Vahan Agopyan e vice-reitor Prof. Dr. Antonio Carlos Hernandes.

Á Faculdade de Odontologia de Ribeirão Preto da Universidade de São Paulo, na pessoa da atual Diretora Prof ${ }^{a}$. Dra . Léa Assed Bezerra da Silva e do Vice-diretor Prof. Dr. Arthur Belém Novaes Júnior e à Coordenação do Curso de Pós-Graduação em Odontopediatria da Faculdade de Odontologia de Ribeirão Preto da Universidade de São Paulo, na pessoa da coordenadora Profa. Dra. Raquel Assed Bezerra Segato e à vicecoordenadora Profa. Dra. Léa Assed Bezerra da Silva.

Ao meu orientador Prof. Dr. Fabrício Kitazono de Carvalho, por me ajudar na introdução em minha vida acadêmica, bem como toda a paciência e disponibilidade ao longo da execução desse trabalho.

Aos professores do Departamento de Clínica Infantil da Faculdade de Odontologia de Ribeirão Preto da Universidade de São Paulo, verdadeiros exemplos de mestres que devo seguir em minha carreira acadêmica.

À Profa. Dra. Lusânia Maria Greggi Antunes da Faculdade de Ciências Farmacêuticas de Ribeirão Preto da Universidade de São Paulo, bem como aos funcionários e pós-graduandos do Laboratório de Nutrigenômica, em especial à Regislaine Valéria Burim e Tássia Rafaella Costa, por todo o auxílio tanto técnico como acadêmico.

A todo o pessoal técnico envolvido no desenvolvimento do presente trabalho, em especial à Nilza Letícia Magalhães, que contribuiu não somente na execução laboratorial do projeto, bem como seu apoio moral, sempre me dizendo "Vai dar certo!".

Aos funcionários do Departamento de Clínica Infantil, em especial Micheli Cristina Leite Rovanholo, Matheus Morelli Zanela e Filomena Leli Placciti, sempre dispostos a nos ajudar. 
Aos pós-graduandos em Odontopediatria da Faculdade de Odontologia de Ribeirão Preto da Universidade de São Paulo, um agradecimento especial aos meus colegas de turma de Mestrado Daniela Verardi, Marjorie Omori, Raí Carvalho, Sílvia Yacarini e Stephanie Diaz. Com certeza não ter estado em turma melhor, pois nos relacionamos com profundo respeito e além de tudo, amizade sincera!

Muito obrigada por terem passado esse tempo comigo; às minhas colegas de Pósgraduação Ana Caroline Fumes e Francine Lorencetti, por terem me guiado principalmente no início do curso, além de suas amizades; à aluna Bárbara Fortunato, por ter participado do projeto e me auxiliado em tantas buscas bibliográficas.

À Coordenação de Aperfeiçoamento de Pessoal de Nível Superior (CAPES) pela bolsa concedida.

Aos professores da banca examinadora e suplentes, por terem aceito o convite e pela atenção dispensada na leitura dessa dissertação. 
VICIONI-MARQUES, F. Propriedades físico-químicas e citotoxicidade de materiais obturadores de canais radiculares de dentes permanentes. Ribeirão Preto, 2018. 94p. Dissertação (Mestrado) Faculdade de Odontologia de Ribeirão Preto, Universidade de São Paulo.

\section{RESUMO}

O presente estudo teve como objetivo avaliar as propriedades físico-químicas e citotoxicidade quatro cimentos endodônticos, com diferentes bases químicas, utilizados na rotina clínica do Cirurgião-dentista. Foram utilizados os cimentos AH Plus ${ }^{\circledR}$, BioRoot RCS ${ }^{\circledR}$, Endomethasone $\mathrm{N}^{\circledR}$ e Sealapex ${ }^{\circledR}$. Foram realizados os testes físico-químicos de tempo de endurecimento, radiopacidade e escoamento, segundo a especificação $n^{\circ} 57$ da ANSI/ADA (2012). Para o teste de citotoxicidade, foram coletadas amostras sanguíneas de seis doadores voluntários adultos, com idade entre 18 e 35 anos, de ambos os gêneros. Foi realizada a cultura de células primárias de linfócitos do sangue periférico humano em contato com o eluato dos cimentos obturadores, e a viabilidade celular foi analisada por meio do ensaio de MTT. Cada teste foi realizado em triplicata, tanto para propriedades físico-químicas como para o ensaio do MTT, sendo os resultados analisados empregando o programa GraphPad Prism $5^{\circledR}$, por meio do teste Oneway ANOVA e pós-teste de Tukey, com nível de significância de 5\%. De acordo com os resultados obtidos, tanto o AH Plus ${ }^{\circledR}$ quanto o BioRoot $\operatorname{RCS}^{\circledR}$ apresentaram tempo de endurecimento de 1450 minutos e 255 minutos, respectivamente; Endomethasone $\mathrm{N}^{\circledR}$ não tem tempo de endurecimento citado pelo fabricante, e Sealapex ${ }^{\circledR}$ não tomou presa no período do estudo (168 horas). Para o teste de radiopacidade, todos os materiais avaliados apresentaram radiopacidade acima de $3 \mathrm{~mm}$ alumínio, como recomendado pela especificação no 57 da ANSI/ADA (2012). Para o teste de escoamento, segundo a ISO 6876:2012, um cimento endodôntico não deve apresentar um diâmetro inferior a $17 \mathrm{~mm}$. Observamos a maior média para AH Plus ${ }^{\circledR}(39,68$ $\mathrm{mm})$, seguido em ordem decrescente por Sealapex ${ }^{\circledR}(35,73 \mathrm{~mm})$, Endomethasone $\mathrm{N}^{\circledR}(34,22$ $\mathrm{mm})$ e BioRoot $\operatorname{RCS}^{\circledR}(23,81 \mathrm{~mm})$. Quanto à viabilidade celular, Endomethasone $\mathrm{N}^{\circledR}$ foi citotóxico sobre os linfócitos em todas as concentrações $(p<0,05)$. Sealapex ${ }^{\circledR}$ apresentou menor viabilidade celular na diluição de 1:32 $(3,125 \mathrm{mg} / \mathrm{mL})(\mathrm{p}<0,05)$. AH Plus ${ }^{\circledR}$ e BioRoot ${ }^{\circledR}$ não demonstrou citotoxicidade em nenhuma das concentrações avaliadas $(p>0,05)$. Podemos concluir que todos os materiais avaliados atenderam aos parâmetros estabelecidos pela ANSI/ADA para os testes físico-químicos realizados. Além disso, o Endomethasone $\mathrm{N}^{\circledR}$ apresentou citotoxicidade sobre os linfócitos humanos, e os demais materiais analisados apresentaram viabilidade celular em níveis aceitáveis.

Palavras-chave: Endodontia. Citotoxicidade. Obturação do canal radicular. Análises físicoquímicas. Materiais obturadores do canal radicular. 

VICIONI-MARQUES, F. Physicochemical properties and cytotoxicity of root canal filling materials of permanent teeth. Ribeirão Preto, 2018. 94p. Master's Degree - School of Dentistry of Ribeirão Preto, University of São Paulo.

\begin{abstract}
The present study had as objective to evaluate the physicochemical properties and cytotoxicity of four root canal sealers with different chemical bases, used in the clinical routine of the Dentistry. The AH Plus ${ }^{\circledR}$, BioRoot RCS ${ }^{\circledR}$, Endomethasone $\mathrm{N}^{\circledR}$ and Sealapex ${ }^{\circledR}$ cements were used. The physicochemical tests of setting time, radiopacity and flowability were performed according to ANSI/ADA specification ( ${ }^{\circ} 57$ ). For the cytotoxicity test, blood samples were collected from six adult voluntary donors, aged 18-35 years, of both genders. Primary human lymphocyte cell cultures were placed in contact with the eluate from the plug cements, and cell viability was analyzed by the MTT assay. Each test was performed in triplicate, both for physicochemical properties and for the MTT assay. The results were analyzed using the GraphPad Prism $5^{\circledR}$ program, using the Oneway ANOVA test and Tukey's post-test, with a significance level of 5\%. According to the results obtained, both AH Plus ${ }^{\circledR}$ and BioRoot RCS $^{\circledR}$ presented setting time of 1450 minutes and 255 minutes, respectively; Endomethasone $\mathrm{N}^{\circledR}$ does not have setting time quoted by the manufacturer, and Sealapex ${ }^{\circledR}$ did not set in the study period (168 hours). For the radiopacity test, all evaluated materials had radiopacity above $3 \mathrm{~mm}$ aluminum, as recommended by the ANSI/ADA specification $\left(n^{\circ}\right.$ 57). For the flow test, according to ISO 6876:2012, an endodontic cement must not have a diameter of less than $17 \mathrm{~mm}$. We observed the highest mean for AH Plus ${ }^{\circledR}(39.68 \mathrm{~mm})$, followed in descending order by Sealapex ${ }^{\circledR}(35.73 \mathrm{~mm})$, Endomethasone $\mathrm{N}^{\circledR}(34.22 \mathrm{~mm})$ and BioRoot RCS ${ }^{\circledR}$ $(23.81 \mathrm{~mm})$. Regarding cell viability, Endomethasone $\mathrm{N}^{\circledR}$ was cytotoxic on lymphocytes at all concentrations $(\mathrm{p}<0.05)$. Sealapex ${ }^{\circledR}$ presented lower cell viability at $1: 32$ dilution $(3.125 \mathrm{mg} / \mathrm{mL})$ $(\mathrm{p}<0.05)$. AH Plus ${ }^{\circledR}$ and BioRoot ${ }^{\circledR}$ showed no cytotoxicity at any of the concentrations evaluated (p>0.05). We can conclude that all materials evaluated met the parameters established by ANSI/ADA for the physicochemical tests performed. In addition, Endomethasone $\mathrm{N}^{\circledR}$ showed cytotoxicity on human lymphocytes, and the other materials analyzed presented cell viability at acceptable levels.
\end{abstract}

Keywords: Endodontics. Cytotoxicity. Root canal obturation. Physicochemical analysis. Root canal filling materials. 



\section{LISTA DE FIGURAS}

Figura 1. Gráficos representativos dos testes de tempo de endurecimento, radiopacidade e escoamento, para os materiais AH Plus ${ }^{\circledR}$, Endomethasone $\mathrm{N}^{\circledR}$, Sealapex ${ }^{\circledR}$ e BioRoot RCS ${ }^{\circledR}$...

Figura 2. Figura representativa da avaliação de viabilidade celular por meio do ensaio do MTT.

Figura 3. Gráficos representativos do teste de citotoxicidade por meio de avaliação da viabilidade celular no MTT, para os materiais AH Plus ${ }^{\circledR}$, Sealapex ${ }^{\circledR}$, Endomethasone $\mathrm{N}^{\circledR}$ e BioRoot $\mathrm{RCS}^{\circledR}$, em comparação ao controle positivo $(\mathrm{CP})$ e negativo $(\mathrm{CN})$.

Figura 4. Gráficos representativos do teste de citotoxicidade por meio de avaliação da viabilidade celular no MTT para os materiais AH Plus ${ }^{\circledR}$, Sealapex ${ }^{\circledR}$, Endomethasone $\mathrm{N}^{\circledR}$ e BioRoot $\mathrm{RCS}^{\circledR}$, em comparação aos controles positivo (CP) e negativo (CN), nas diluições de 1:2, 1:4, 1:8, 1:16, $1: 32$ 



\section{LISTA DE TABELAS}

Tabela 1. Composição de cada material estudado e fabricante 40

Tabela 2. Valores de média para os testes tempo de endurecimento (minutos), teste de escoamento (milímetros) e radiopacidade (milímetros de Alumínio) e desvio padrão (DP) para os diferentes materiais 50 



\section{SUMÁRIO}

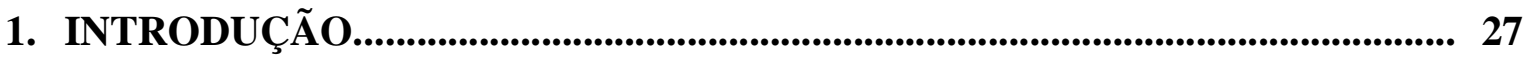

2. PROPOSIÇÃO.................................................................................................................... 35

3. MATERIAL E MÉTODOS........................................................................ 39

3.1 Materiais obturadores a serem avaliados........................................................ 39

3.2 Avaliação das propriedades físico-químicas dos cimentos obturadores de canais radiculares............................................................................... 41

3.2.1 Tempo de endurecimento.................................................................. 41

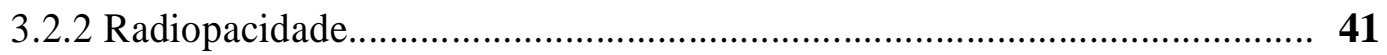

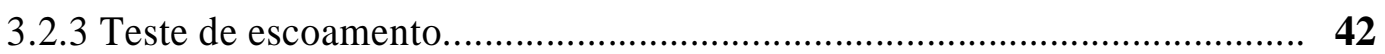

3.3 Avaliação da citotoxicidade dos cimentos obturadores de canais radiculares, por $\mathbf{4 3}$ meio do MTT.

3.3.1 Procedimentos éticos......................................................................... 43

3.3.2 Preparo das culturas celulares.............................................................. 43

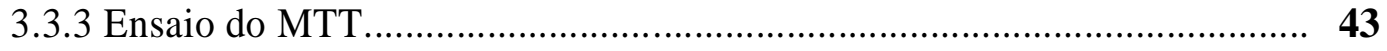

3.3.4 Determinação da validade do ensaio......................................................... 44

3.4 Análise estatística.................................................................................. 45

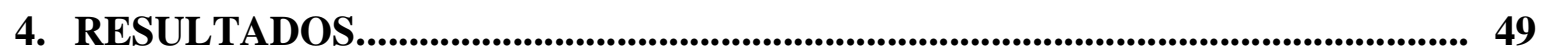

4.1 Tempo de endurecimento............................................................................... 49

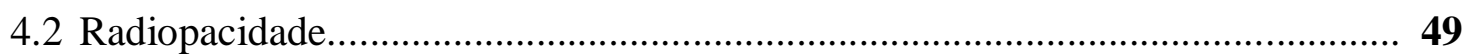

4.3 Teste de escoamento.................................................................................... 50

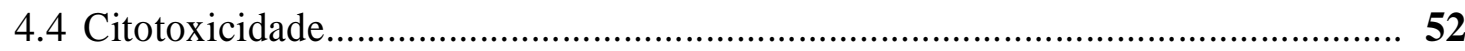

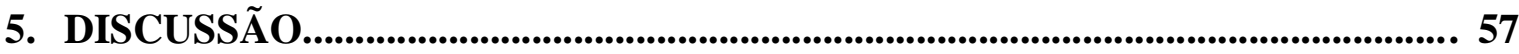

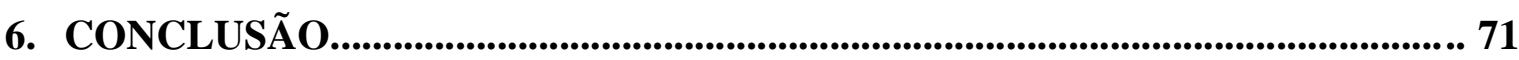

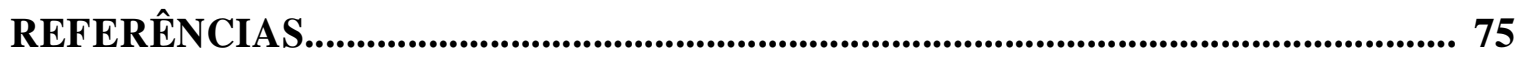

ANEXOS........................................................................................................................................ 91 

1. Intraduçãa 



\section{INTRODUÇÃO}

O objetivo da obturação do sistema de canais radiculares é tornar hermético o espaço modelado pelo preparo biomecânico. Para isso, os materiais obturadores auxiliam no preenchimento das irregularidades existentes entre o cone de guta-percha e as paredes do canal radicular sendo que, durante esse processo, os materiais endodônticos e seus produtos de degradação podem entrar em contato direto com as células dos tecidos apicais e periapicais (Willersshausen et al., 2013; Yoshino et al., 2013; Diomede et al., 2014; Camps et al., 2015; Garrido et al., 2015; Rodríguez-Lozano et al., 2015; Cintra et al., 2017; Collado-González et al., 2017; Rodríguez-Lozano et al., 2017; Teixeira et al., 2017; Jung et al., 2018).

Para se obter sucesso após o tratamento endodôntico, a seleção do material obturador adequado é tão essencial como a técnica operatória, tendo em vista que os cimentos endodônticos são geralmente irritantes aos tecidos periapicais (Garrido et al., 2015). Alguns autores demonstraram que quando se realiza a condensação do material obturador endodôntico, pode ocorrer extravasamento em direção aos tecidos periapicais, estimulando alterações celulares e respostas inflamatórias (Willershausen et al., 2011; Mendonça e Estrela 2001; Cotti et al., 2014; Ruparel, 2014).

Segundo Consolaro e Bittencourt (2014), o extravasamento do material no periodonto apical dificulta o processo de reparo, sendo que as consequências podem permanecer como lesões inflamatórias crônicas. Dessa forma, torna-se indispensável que os materiais obturadores de canais radiculares sejam bem aceitos pelos tecidos perriradiculares, visto que estes materiais podem ficar em contato direto com os tecidos periapicais por período indeterminado de tempo. Ainda, esses materiais podem ser extravasados na forma de "puff", e ainda os componentes derivados desses materiais podem vir a entrar em contato direto com os tecidos por numerosas conexões, incluindo túbulos dentinários, canais acessórios, canais laterais e o forame apical (Koch, 2001), o que leva à irritação e reparação tardia, provocando também possível desconforto pós-operatório (Tepel et al., 1994; Geurtsen e Leyhausen 1997; Tanomaru Filho et al., 1998; Hauman e Love 2003; Schafer e Zandbiglari 2003; Seltzer, 2004; Huang et al., 2005; Donnelly et al., 2007; Spagnuolo et al., 2008; Badole et al., 2013; Reichl et al. 2015; RodríguezLozano et al., 2015). Outros estudos mostram, também, que a toxicidade de certos materiais varia de acordo com o período, sendo que a maioria apresenta citotoxicidade (Gerosa et al., 1995; Leonardo et al., 1999; Huang, Lee e Kao 2001).

Verifica-se, assim, que quando a obturação dos canais radiculares é efetuada, o cimento endodôntico permanecerá por longo período em contato com as células do ligamento 
periodontal. Por essa razão, deve apresentar biocompatibilidade, que é definida como a capacidade de um material exercer suas funções específicas, quando aplicado em tecidos vivos, sem causar danos ou prejuízos ao mesmo (Jorge, 2004; Anusavice, 2013). Caso não apresente compatibilidade tecidual, o material induzirá citotoxicidade, reações inflamatórias, alérgicas ou genotóxicas, podendo contribuir com danos celulares relacionados ao surgimento de neoplasias, inclusive à distância, já que o ligamento periodontal é altamente vascularizado (Van Landuyt et al., 2012; Lima et al., 2016). Esta propriedade relaciona-se diretamente com a composição dos materiais. Como exemplo, pode ser citada a liberação de substâncias tóxicas por materiais à base de óxido de zinco e eugenol, se mantidos durante um período prolongado, podendo manter uma inflamação constante (Zmener et al., 2012); ainda, os materiais à base de metacrilato possuem alguns componentes que podem não polimerizar e são tóxicos para os tecidos periapicais (Augsburger e Peters, 1990); e materiais que contém resina epóxi apresentam um grau de citotoxicidade (Huang et al., 2002; Eldeniz et al., 2007) e inflamação severa (Holland e Souza, 1985; Huang et al., 2003), sendo alguns considerados mutagênicos para liberação de bisfenol A, éter diglicidílico e formaldeído, substâncias potencialmente carcinogênicas (Camargo et al., 2009).

Os materiais obturadores podem ser classificados de acordo com sua composição química, apresentando-se como cimentos à base de óxido de zinco e eugenol, cimentos contendo hidróxido de cálcio, cimentos à base de resina, cimentos à base de ionômero de vidro, à base de MTA, à base de biocerâmicas e aqueles à base de silicone (Yoshimine et al, 2003; Baraba et al., 2011; AL-Haddad e Aziz, 2016). Esses materiais devem possuir propriedades físico-químicas satisfatórias, como bom escoamento, selamento hermético do canal radicular, resistência à contração, ser insolúvel aos fluidos bucais, ser bacteriostático ou impróprio para a proliferação microbiana, ser radiopaco, não interferir na coloração dentária e não ser irritante aos tecidos periapicais (Lee 2002; Wu et al., 2006; Gatewood, 2007; Ozorio, 2012).

\section{Em 1983, a American National Standards Institute/American Dental Association} (ANSI/ADA) instituiu uma série de normas e testes, chamada de Especificação no 57, para avaliação das propriedades físico-químicas de materiais obturadores, a fim de padronizar os testes e promover uma maior qualidade científica nas pesquisas. Essa especificação foi revisada no ano de 2012, sendo composta pelos seguintes testes: escoamento, tempo de trabalho, tempo de endurecimento, espessura do filme, solubilidade e desintegração e radiopacidade.

Os materiais obturadores devem ser dimensionalmente estáveis, radiopacos e insolúveis (Whitworth, 2005). A resistência à infecção bacteriana depende principalmente da 
integridade do material obturador e, por isso, esse material deve apresentar baixa solubilidade. Outra propriedade importante é a radiopacidade, que permite-nos avaliar a qualidade da obturação do canal radicular (Gambarini et al., 2006; Carvalho-Junior et al., 2007). Além disso, o tempo de endurecimento do material deve ser suficientemente longo para garantir o fácil manuseio, mesmo quando se utilizam técnicas de obturação que levam mais tempo para serem concluídas (Schäfer et al., 2015).

Em 2012, Marín-Bauza et al. em avaliaram o tempo de endurecimento, teste de escoamento, radiopacidade, solubilidade e alteração dimensional de diferentes materiais obturadores (AH Plus ${ }^{\circledR}$, Polifil $^{\circledR}$, Apexit Plus ${ }^{\circledR}$, Sealapex $^{\circledR}$, Endomethasone $^{\circledR}$ e Endofill $^{\circledR}$ ) de acordo com a especificação $\mathrm{n}^{\circ} 57$ da ANSI/ADA. Para o tempo de endurecimento, os materiais AH Plus ${ }^{\circledR}$, Apexit $^{\circledR}$ e Endofil ${ }^{\circledR}$ estavam de acordo com os padrões da ANSI/ADA, sendo que o Endomethasone ${ }^{\circledR}$ apresentou o maior tempo de média para esse teste (644 minutos), seguido de AH Plus ${ }^{\circledR}$, (579 minutos). O menor tempo foi registrado pelo Endofill ${ }^{\circledR}$, e Sealapex ${ }^{\circledR}$, não apresentou presa. Considerando os testes de radiopacidade, solubilidade e alteração dimensional, todos os cimentos obturadores estavam de acordo com a ANSI/ADA.

Em 2013, Chávez-Andrade et al. investigaram o escoamento, tempo de endurecimento, $\mathrm{pH}$, liberação de cálcio e força de adesão de um cimento à base de MTA (MTA Fillapex ${ }^{\circledR}$ ), em comparação ao AH Plus ${ }^{\circledR}$ e Sealapex ${ }^{\circledR}$. O teste de escoamento foi baseado na ISO 6876:2001(International Standart Organization) e para o teste de tempo de endurecimento foi utilizada a especificação ASTM C266-03. A fluidez de todos os materiais foi estatisticamente semelhante $(\mathrm{p}>0,05)$. Os tempos de endurecimento foram diferentes entre os grupos testados (MTA Fillapex ${ }^{\circledR}<$ Sealapex $^{\circledR}<$ AH Plus $\left.{ }^{\circledR}\right)(\mathrm{p}<0,05)$. Os autores concluíram que o MTA Fillapex ${ }^{\circledR}$ e o Sealapex ${ }^{\circledR}$ apresentaram várias propriedades semelhantes entre si, e ambos foram diferentes para do AH Plus ${ }^{\circledR}$.

Khalil et al., em 2016, realizaram um estudo com o objetivo de caracterizar e investigar as propriedades de um novo material obturador à base de silicato tricálcio. $\mathrm{O}$ novo material $\left(\right.$ Bio $\mathrm{MM}^{\circledR}$ ), BioRoot $\mathrm{RCS}^{\circledR}$ e AH Plus ${ }^{\circledR}$ foram analisados para verificar sua conformidade com a ISO 6876 (2012). Como resultados obtiveram que AH Plus cumpriu o que é especificado na ISO para escoamento e espessura do filme. O BioRoot $\mathrm{RCS}^{\circledR}$ e o Bio $\mathrm{MM}^{\circledR}$ exibiram um menor escoamento e maior espessura de filme do que é estabelecido pela ISO 6876:2012. Todos os materiais apresentaram radiopacidade adequada.

Prüllage et al. (2016) compararam a solubilidade, a radiopacidade e o tempo de endurecimento de um cimento obturador à base de silicato de tricálcio (BioRoot RCS ${ }^{\circledR}$ ) e outro à base de mineral trióxido agregado (MTA Fillapex ${ }^{\circledR}$ ), em relação a um material à base de resina 
epóxica (AH Plus ${ }^{\circledR}$ ). A solubilidade em água destilada, a radiopacidade e o tempo de endurecimento foram avaliados de acordo com a ISO 6876 (2012). A radiopacidade de todos os materiais foi superior a $3 \mathrm{~mm}$ de alumínio, sem diferença estatisticamente semelhante entre eles ( $p>0,05)$. O tempo de endurecimento final foi de $324( \pm 1)$ minutos para o BioRoot $\mathrm{RCS}^{\circledR}$ e $612( \pm 4)$ minutos para o AH Plus ${ }^{\circledR}$, sendo a diferença estatisticamente significante entre eles $(\mathrm{p}<0,05)$.

Por outro lado, o uso de cultura de células in vitro faz parte dos protocolos mais utilizados dentre as várias metodologias recomendadas para avaliar a biocompatibilidade e a citotoxicidade de materiais dentários, em diferentes níveis de investigação (Ratanasathien et al., 1995; Martins et al., 2013). Esse fato deve-se à homogeneidade que as amostras apresentam e uma fácil padronização, sendo possível o controle de fatores como $\mathrm{pH}$, temperatura, pressão osmótica e tensão de $\mathrm{O}_{2}$ e $\mathrm{CO}_{2}$ (Freshney, 2005). Com isso, pode-se ressaltar a cultura de células primárias, que são produzidas a partir de células retiradas de um tecido por processos de desagregação mecânica, enzimática ou química. Essas células possuem morfologia idêntica ao do tecido das quais se originam, sendo que sua cultura permite poucas divisões (ou passagens) celulares, entrando após esse processo em estado de senescência e morte, dessa forma podendo assim ser consideradas representativas das condições naturais de um organismo (Schmalz, 1994; Martins et al., 2013). A cultura primária pode ser obtida de células retiradas do sangue, órgãos (rins, fígado, linfonodos, baço, timo e pâncreas) e organismos (embriões) (Takahashi et al., 1990).

De acordo com a ISO 10993-5, o primeiro teste para avaliar a biocompatibilidade de qualquer material para uso em dispositivos biomédicos é o ensaio de citotoxicidade in vitro. Dentre os vários testes para avaliação da citotoxicidade in vitro de diversos materiais, um deles é o ensaio do MTT (3-(4,5-dimetiltiazol-2il)-2-5-difenil-2H tetrazolato de bromo), que avalia a viabilidade celular por meio da atividade mitocondrial, sendo bem aceito na literatura para avaliação de materiais endodônticos (Al-Hiyasat, Tayyar e Darmani 2010; Ashraf et al., 2012; Scelza, Coil e Alves 2012; Candeiro et al., 2015; Mestieri et al. 2015; Rodríguez-Lozano et al., 2015; Silva et al., 2015; Cintra et al., 2017).

Em 2012, Bin et al. analisaram a citotoxicidade dos cimentos endodônticos à base de agregado trióxido mineral (Fillapex ${ }^{\circledR}$ ), em comparação ao cimento MTA branco e ao AH Plus ${ }^{\circledR}$. Fibroblastos de hamster chinês (V79) foram colocados em contato com diferentes diluições das culturas previamente expostas aos materiais. A citotoxicidade foi avaliada pelo ensaio MTT em espectrofotômetro, para checar a viabilidade e a sobrevivência das células. Os resultados mostraram que a viabilidade celular se manteve acima de 50\% no grupo do MTA $^{\circledR}$ branco para 
todas as diluições. O AH Plus ${ }^{\circledR}$ induziu citotoxicidade intermediária, seguido pelo cimento Fillapex MTA $^{\circledR}$.

Candeiro et al., em 2015, compararam as características do cimento à base de biocerâmica (Endosequence $\mathrm{BC}^{\circledR}$ ) e o $\mathrm{AH}$ Plus ${ }^{\circledR}$, com relação à citotoxicidade em fibroblastos gengivais humanos expostos ao meio de cultura de células condicionado pelos cimentos, utilizando o ensaio MTT. As células (fibroblastos gengivais humanos) foram cultivadas em meio fresco serviram como controle. Culturas expostas ao Endosequence $\mathrm{BC}^{\circledR}$ tiveram viabilidade significativamente maior, em comparação ao cimento $\mathrm{AH}$ Plus ${ }^{\circledR}$. O cimento à base de biocerâmica apresentou menor citotoxicidade em comparação ao cimento AH Plus ${ }^{\circledR}$.

A citotoxicidade de dois cimentos endodônticos experimentais à base de resina natural com extratos de Copaifera multijuga e Ricinus communis, comparados com cimentos à base de resina sintética - Metacrilato (EndoREZ ${ }^{\circledR}$ ), multi-metacrilato (RealSeal SE ${ }^{\circledR}$ ) e epóxi $\left(\right.$ AHPlus $^{\circledR}$ ) foram avaliadas por Silva et al. em 2016. Os extratos dos cimentos foram preparados e expostos ao meio de cultura com células V79, sendo a viabilidade celular analisada pelo ensaio MTT. Os materiais testados à base de resina natural apresentaram baixo efeito citotóxico.

Em 2017, Cintra et al avaliaram a citotoxicidade e a biocompatibilidade tecidual de um novo cimento endodôntico à base de resina, utilizando como comparação o AH Plus ${ }^{\circledR}$, Endofill $^{\circledR}$ e Simpli-Seal ${ }^{\circledR}$. Foram utilizados fibroblastos L929 e o ensaio MTT para determinar a citotoxicidade dos extratos. Além disso, tubos contendo o extrato dos materiais e controles foram inseridos subcutaneamente em ratos, e foram removidos após 7 e 30, dias para análise histológica. O novo material (Sealer Plus ${ }^{\circledR}$ ) promoveu maior viabilidade celular e foi maior compatibilidade tecidual, em comparação com os outros materiais.

Pelo exposto, verifica-se que na literatura específica há poucos trabalhos que avaliam a citotoxicidade de materiais obturadores em linfócitos humanos periféricos, por meio do ensaio do MTT. Ainda, continuamente novos materiais são introduzidos no comércio especializado, sendo imprescindível avaliar sua biocompatibilidade e propriedades físico-químicas, para que esses materiais possam ser utilizados na prática clínica de fato mais segura. 

2. Prapasiçãa 



\section{PROPOSIÇÃO}

O objetivo do presente estudo foi avaliar propriedades físico-químicas e a citotoxicidade dos seguintes cimentos obturadores do canal radicular: AH Plus ${ }^{\circledR}$ (à base de resina epóxica); BioRoot $\operatorname{RCS}^{\circledR}$ (à base de silicato de cálcio); Endomethasone $\mathrm{N}^{\circledR}$ (à base de óxido de zinco e eugenol) e Sealapex ${ }^{\circledR}$ (à base de hidróxido de cálcio).

Objetivos específicos:

$\checkmark$ Avaliação de propriedades físico-químicas (Tempo de endurecimento, radiopacidade e teste de escoamento) dos 4 cimentos obturadores do canal radicular, considerando os padrões estabelecidos pela ANSI/ADA;

$\checkmark$ Avaliação da citotoxicidade, por meio do ensaio de MTT em cultura de linfócitos do sangue periférico humano. 

3. Material e Métadas 



\section{MATERIAL E MÉTODOS}

\subsection{Materiais obturadores de canais radiculares a serem avaliados}

Foram avaliados quatro materiais obturadores de canais radiculares utilizados em dentes permanentes, entre eles: AH Plus ${ }^{\circledR}$ (Dentsply, Konstanz, Alemanha), Endomethasone $\mathrm{N}^{\circledR}$ (Septodont, Saint-Maur-des-Fossés, França), BioRoot RCS ${ }^{\circledR}$ (Septodont, Saint-Maur-desFossés, França) e Sealapex ${ }^{\circledR}$ (Kerr, Orange, EUA). A tabela 1 apresenta a composição e o fabricante dos materiais avaliados. 
Tabela 1 - Composição de cada material estudado e fabricante.

\begin{tabular}{|c|c|c|}
\hline Material & Componente & Ingredientes \\
\hline \multirow[t]{2}{*}{$\begin{array}{c}\text { AH Plus }{ }^{\circledR} \\
\text { (Dentsply, Konstanz, } \\
\text { Alemanha) }\end{array}$} & Pasta A & $\begin{array}{l}\text { Resina epóxica, bisfenol-A } \\
\text { e bisfenol-B, tungstato de } \\
\text { cálcio, óxido de zircônio, } \\
\text { sílica, óxido de ferro }\end{array}$ \\
\hline & Pasta B & $\begin{array}{l}\text { Amina1-adamantano N, N'- } \\
\text { dibenzoil-5-oxanonane- } \\
\text { diamina-1,9-TCD-diamina, } \\
\text { tungstato de cálcio, óxido de } \\
\text { zircônio, óleo de silicone, } \\
\text { aerosil }\end{array}$ \\
\hline $\begin{array}{c}\text { BioRoot }^{\circledR} \\
\text { (Septodont, Saint-Maur- } \\
\text { des-Fossés, França) }\end{array}$ & & $\begin{array}{l}\text { Silicato tricálcio e óxido de } \\
\text { zircônio }\end{array}$ \\
\hline \multirow[t]{2}{*}{$\begin{array}{c}\text { Endomethasone } \mathbf{N}^{\circledR} \\
\text { (Septodont, Paris, } \\
\text { França) }\end{array}$} & Pó & $\begin{array}{l}\text { Acetato de hidrocortisona, } \\
\text { iodeto de timol, óxido de } \\
\text { zinco, estereato de } \\
\text { magnésio, excipiente } \\
\text { radiopaco }\end{array}$ \\
\hline & Líquido & Eugenol \\
\hline \multirow[t]{2}{*}{$\begin{array}{c}\text { Sealapex }^{\circledR} \\
\text { (Kerr, Orange, EUA) }\end{array}$} & Pasta base & $\begin{array}{l}\text { Óxido de cálcio, óxido de } \\
\text { zinco, sulfonamidas, sílica }\end{array}$ \\
\hline & Pasta catalisadora & $\begin{array}{c}\text { Trióxido de bismuto, } \\
\text { polimetilmetacrilato, } \\
\text { metilsalicilato, dióxido de } \\
\text { titânio, sílica, pigmentos, } \\
\text { isobutilsalicilato }\end{array}$ \\
\hline
\end{tabular}




\subsection{Avaliação das propriedades físico-químicas dos cimentos obturadores de canais radiculares}

Os seguintes testes físico-químicos foram realizados, seguindo a especificação $\mathrm{n}^{\mathrm{o}} 57$ da ANSI/ADA (American National Standards Institute/American Dental Association) (2012).

\subsubsection{Tempo de endurecimento}

Foram utilizados anéis de cloreto de polivinila (PVC) com 10mm de diâmetro por $2 \mathrm{~mm}$ de altura para cada cimento testado, os quais permaneceram sobre uma placa de vidro de $1 \mathrm{~mm}$ de espessura por $25 \mathrm{~mm}$ de largura e $75 \mathrm{~mm}$ de comprimento. Os cimentos foram manipulados de acordo com as instruções dos fabricantes e colocados no interior dos anéis até que estes ficassem totalmente preenchidos. Todo o conjunto permaneceu em estufa a $37^{\circ} \mathrm{C}$. Após 30 minutos do início da manipulação, uma agulha tipo Gillmore de $112 \mathrm{~g}$ e ponta ativa de $2 \mathrm{~mm}$ de diâmetro foi colocada verticalmente sobre a superfície do material. O uso da agulha foi repetido até que não provocasse mais marcas no cimento testado, o que evidenciou a presa inicial do material. Posteriormente, uma agulha tipo Gillmore de $454 \mathrm{~g}$ e ponta ativa de $1,06 \mathrm{~mm}$ de diâmetro foi colocada verticalmente sobre a superfície do material. A inserção da agulha foi repetida até que parasse de marcar o cimento, o que indicou a presa final do material. O tempo de endurecimento foi o decorrido entre o início da mistura e o momento no qual as marcas da agulha Gillmore deixaram de ser visíveis na superfície do cimento testado. O teste foi realizado em triplicata para cada cimento obturador, obtendo-se uma média aritmética que representou o tempo de endurecimento dos materiais.

\subsubsection{Radiopacidade}

Para a realização desse teste, foram confeccionadas placas de acrílico de $1 \mathrm{~mm}$ de espessura, $1 \mathrm{~cm}$ de largura e 4,5cm de comprimento, contendo quatro perfurações de $5 \mathrm{~mm}$ de diâmetro interno cada. Cada perfuração da placa foi preenchida com um dos cimentos testados, sobre os quais foi colocada uma placa de vidro envolta em lâmina de papel celofane. Todo esse conjunto foi pressionado de forma que o excesso de cimento extravasasse e, dessa forma, fosse obtida uma amostra de $1 \mathrm{~mm}$ de espessura por $5 \mathrm{~mm}$ de diâmetro, de cada material. O experimento foi realizado em triplicata para cada cimento obturador.

Os cimentos foram inseridos nas placas de acrílico seguindo a sequência de acordo com o tempo de endurecimento de cada material, do tempo mais longo para o mais curto. Desta forma, as amostras ficaram prontas para a avaliação radiográfica, simultaneamente, ao final de 
um período equivalente a três vezes o tempo de endurecimento dos materiais. Neste período as placas foram armazenadas em estufa a $37^{\circ} \mathrm{C}$ e umidade relativa de $95 \%$.

Cada placa de acrílico, já preenchida com os cimentos, foi colocada à frente do sensor radiográfico com distância foco-objeto de $30 \mathrm{~cm}$ e ao lado da placa, sendo colocada também uma escada de alumínio 99\% (liga 1100), com espessura variada de 1 a 10mm, com degraus uniformes de $1 \mathrm{~mm}$, o que em uma mesma tomada radiográfica, permitiu a comparação entre os degraus da escada de alumínio e as respectivas amostras. Posteriormente, foram obtidas as imagens radiográficas das amostras dos materiais e da escada, com o auxílio de filme radiográfico oclusal (Insight IO-41 - Carestream Health, Inc., Rochester, NY, EUA) e aparelho de raios-X (Gnatus Equipamentos Médicos-Odontológicos LTDA., Ribeirão Preto, SP, Brasil), na Clínica de Odontopediatria da Faculdade de Odontologia de Ribeirão Preto - USP, com distância foco-filme de $30 \mathrm{x} \mathrm{cm}$ e ajuste para exposição de $70 \mathrm{kVp}$ e $7 \mathrm{~mA}$, por 0,2 segundos. Os filmes foram processados e secos em reveladora automática (Air Techniques Inc., Melville, New York, EUA).

Após a obtenção das radiografias, essas foram posicionadas em negatoscópio profissional e digitalizadas com o auxílio de uma câmera fotográfica digital (Canon Rebel T5i, com objetiva Canon EF Macro 100mm-f/1:2.8, diafragma utilizado f/16, tempo de exposição $1 / 13$ segundos, ISO 200, imagem com 5184x3456 pixels). As imagens foram armazenadas no formato JPEG (Joint Photographic Experts Group). Para a análise das imagens radiográficas foi utilizado o histograma da intensidade das escalas de tons no "canal luminosidade" do programa Image J (National Institutes of Health, EUA).

\subsubsection{Teste de escoamento}

Os cimentos foram manipulados de acordo com as recomendações dos fabricantes, obtendo-se um volume de $0,5 \mathrm{~mL}$ ajustado em seringa Luer de 5,0mL. Cada cimento foi depositado em uma placa de vidro com 10 x cm de largura e 10cm de comprimento. Após 180 segundos do início da manipulação, foi depositado sobre os cimentos um conjunto composto por uma placa de vidro e uma carga adicional de $120 \mathrm{~g}$. Após 10 minutos, o peso adicional foi removido e mediu-se os diâmetros maiores e menores dos discos por meio de um paquímetro digital 6" Western ${ }^{\circledR}$ (China). O teste foi realizado em triplicata para cada grupo, obtendo-se uma média aritmética que representou o escoamento dos materiais. Segundo a ISO 6876:2012, o diâmetro de cada disco não deve ser inferior a $17 \mathrm{~mm}$. 


\subsection{Avaliação da citotoxicidade dos cimentos obturadores de canais radiculares, por meio do MTT}

\subsubsection{Procedimentos Éticos}

O presente projeto foi submetido à análise pelo Comitê de Ética em Pesquisa da Faculdade de Odontologia de Ribeirão Preto (FORP-USP) e aprovado sob protocolo CAAE 41659915.2.0000.5419.

Para a realização dos experimentos foram obtidas amostras sanguíneas de 6 doadores voluntários adultos, com idade entre 18 e 35 anos, de ambos os gêneros, saudáveis, nãofumantes, que não foram expostos à radiação nos últimos três meses e que não fizeram uso de antibióticos ou outros medicamentos por um período de três semanas. Foram obtidos $10 \mathrm{~mL}$ de sangue utilizando seringa e agulhas descartáveis, por profissional da área da saúde com experiência em flebotomia, no Centro de Formação de Recursos Humanos Especializados no Atendimento Odontológico a Pacientes Especiais da Faculdade de Odontologia de Ribeirão Preto.

Extratos dos materiais endodônticos foram preparados logo após sua manipulação, realizada de acordo com instruções do fabricante, na concentração de $0,1 \mathrm{x} \mathrm{g} / \mathrm{mL}$, e mantidos em estufa a $37^{\circ} \mathrm{C}$ por 24 horas (ISO 10993-12), sendo então serão filtrados e condicionados em geladeira a $4^{\circ} \mathrm{C}$, por um período máximo de 30 dias.

\subsubsection{Preparo das culturas celulares}

Os linfócitos foram isolados do sangue total dos voluntários por centrifugação diferencial utilizando gradiente de densidade Ficoll (Histopaque 1077, Sigma Aldrich, St Louis, MO, USA), conforme protocolo do fabricante. Os linfócitos foram coletados em tubos plásticos tipo Falcon, lavados e ressuspendidos na concentração de $4 \times 10^{5}$ células/mL em meio RMPI 1640 suplementado com 10\% de soro fetal bovino e uma mistura de antibióticos (penicilina e estreptomicina). Após 24 horas de incubação a $37^{\circ} \mathrm{C}$ e $5 \%$ de $\mathrm{CO}_{2}$ em estufa de atmosfera úmida (Thermo Eletronic Serviços e Representação Ltda, Maceió, Alagoas, Brasil), foram realizados os experimentos.

\subsubsection{Ensaio do MTT}

O ensaio do MTT foi descrito primeiramente por Mosmann (1983) e consiste na quantificação de células viáveis por meio da colorimetria. Algumas modificações foram feitas 
até então, utilizando o reativo 3-(4,5-dimetiltiazol-2il) -2-5-difenil-2H tetrazolato de bromo, referenciando-se como reativo do MTT.

A atividade metabólica das células é avaliada por esse método, através da quantificação da redução metabólica do MTT a cristais de formazan*. Dessa forma, quanto maior a formação dos cristais de coloração violeta, maior a porcentagem de viabilidade celular.

Os linfócitos foram isolados $\left(1,0 \times 10^{6}\right)$ em placas de 96 poços, seguido por incubação durante 24 horas a $37^{\circ} \mathrm{C}$ em incubadora umidificada contendo $5 \%$ de $\mathrm{CO}_{2}$, sendo as células tratadas após esse período com $100 \mu \mathrm{L}$ de meio de cultura suplementado com soro fetal bovino (controle negativo) ou $100 \mu \mathrm{L}$ de cada extrato em diferentes diluições $(1: 2-50 \mathrm{mg} / \mathrm{mL} ; 1: 4-$ $25 \mathrm{mg} / \mathrm{mL} ; 1: 8-12,5 \mathrm{mg} / \mathrm{mL} ; 1: 16-6,25 \mathrm{mg} / \mathrm{mL} ; 1: 32-3,125 \mathrm{mg} / \mathrm{mL})$. O controle positivo experimental recebeu $100 \mu \mathrm{L}$ de uma solução de metilmetanosulfonato (MMS), que é um agente alquilante e carcinógeno, o qual causa quebra das cadeias duplas do DNA, sendo a placa novamente levada à incubadora por 24 horas a $37^{\circ} \mathrm{C}$. Após o tratamento, os poços receberam $20 \mu \mathrm{L}$ de MTT [3-(4,5-dimetiltiazol-2il) -2-5-difenil-2H tetrazolato de bromo] (Sigma M2128, EUA) $(500 \mu \mathrm{g} / \mathrm{mL}$, concentração final) e as placas foram incubadas novamente durante 3 horas a $37^{\circ} \mathrm{C}$ e $5 \%$ de $\mathrm{CO}_{2}$. Em seguida, as placas foram centrifugadas a $1500 \mathrm{rpm}$ durante 5 minutos e invertidas para descartar o sobrenadante. O "formazan" formado é insolúvel e se precipita no poço, necessitando ser solubilizado antes da leitura; e para isso, $100 \mu \mathrm{L}$ de DMSO (dimetilsulfóxido) (Sigma D2650, EUA) foram adicionados em cada um dos poços. As placas foram mantidas sob agitação até a dissolução completa dos cristais (aproximadamente 20 minutos) e, em seguida, a absorbância a 570nm foi determinada em um microreader Powerwave XS2 (BioTek, Winooski, Vermont, EUA). A porcentagem de viabilidade celular foi calculada a partir da fórmula: \% de células viáveis = (absorbância do tratamento x 100)/média do controle negativo.

\subsubsection{Determinação da validade do ensaio}

A validade do ensaio foi determinada a partir das respostas das células ao tratamento pelos controles positivo (metilmetanosulfonato - MMS) e negativo (meio de cultura RPMI1640 suplementado com soro fetal bovino). O MMS apresenta uma resposta citotóxica dosedependente bem definida na literatura, caracterizando-se com um bom controle positivo para

\footnotetext{
* Cristais de formazan: ocorre a redução por meio de de uma reação enzimática dos sais do tetrazólio (MTT), envolvendo a oxidação do NADH/NADPH catalisada pelo complexo succinato-tetrazoliumredutase presentes em células viáveis. Os sais tetrazólio, quando reduzidos, formam o sal formazan, apresentando-se hidrofóbico e colorido (solubilizado pela adição de DMSO), podendo, então, ser quantificado por espectofotometria.
} 
os tratamentos (Wyatt; Pittman, 2006). A concentração de $100 \mu \mathrm{L}$ de MMS foi selecionada para utilização como controle positivo. O controle celular foi obtido por meio da observação microscópica dos poços de cultura que receberam somente o meio de cobertura.

\subsection{Análise estatística}

Cada ensaio foi feito em triplicata. Os resultados foram analisados pelo software GraphPad Prism $5^{\circledR}$ utilizando o teste One-way ANOVA e pós-teste de Tukey. O nível de significância adotado foi de 5\%. Para o teste de citotoxicidade, todos os tratamentos foram comparados com o controle negativo (RPMI 1640 completo) e positivo (Metilmetanosulfonato - MMS). 
4. Resultadas 



\section{RESULTADOS}

Os testes One-way ANOVA e Tukey foram usados para comparação entre as médias.

\subsection{Tempo de endurecimento}

De acordo com as especificações da ANSI/ADA, o tempo de endurecimento de um cimento endodôntico deve estar dentro do valor de $10 \%$ daquele estabelecido pelos fabricantes. Nesse estudo, o AH Plus ${ }^{\circledR}$ apresentou tempo médio de endurecimento de 1450 minutos, valor compatível com o informado pelo fabricante $\left(24\right.$ horas a $\left.37^{\circ} \mathrm{C}\right)$. O Endomethasone $\mathrm{N}^{\circledR}$ não tem seu tempo de endurecimento citado pelo fabricante, mas nas análises efetuadas no presente estudo pudemos observar um tempo médio de 606 minutos. O Sealapex ${ }^{\circledR}$ apresenta em suas especificações técnicas fornecidas pelo fabricante uma presa inicial de 60 minutos e final de 24 horas, o que não foi observado no presente estudo, ou seja, o material não tomou presa mesmo em um período de 168 horas. O BioRoot RCS $^{\circledR}$ apresentou um tempo de endurecimento, em média, de 255 minutos, próximo ao valor de tempo máximo estabelecido pelo fabricante (4 horas).

Pela análise estatística de ANOVA e pós-teste de Tukey, o tempo de endurecimento apresentou diferença estatisticamente significante entre os materiais $(p<0,05)$. O AH Plus ${ }^{\circledR}$ apresentou maior valor de média, seguido por Endomethasone $\mathrm{N}^{\circledR}$ e BioRoot ${ }^{\circledR}$. O Sealapex ${ }^{\circledR}$ não apresentou resultados para esse teste, uma vez que não sofreu endurecimento após 168 horas.

\subsection{Teste de radiopacidade}

Todos os materiais apresentaram radiopacidade acima de $3 \mathrm{~mm}$ alumínio, como recomendado pela especificação $n^{\circ} 57$ da ANSI/ADA (2012). O AH Plus ${ }^{\circledR}$ apresentou o maior valor de média $(150,23 \mathrm{mmAL})$ dentre os materiais testados, seguido pelo BioRoot ${ }^{\circledR}(138,70$ mmAL) e Sealapex ${ }^{\circledR}\left(134,37\right.$ mmAL). O Endomethasone $N^{\circledR}$ apresentou a menor média $(121,85$ mmAL) em comparação com os demais materiais testados. Em comparação à escada de Alumínio utilizada para medir a radiopacidade. O Endomethasone $\mathrm{N}^{\circledR}$ e o BioRoot RCS ${ }^{\circledR}$ corresponderam ao degrau 3mm de Alumínio; o Sealapex ${ }^{\circledR}$ ao degrau 4mm Alumínio e o AH Plus $^{\circledR}$ ao degrau 5mm Alumínio. Não foi observada diferença estatisticamente significante na radiopacidade de diferentes materiais avaliados $(\mathrm{p}>0,05)$. 


\subsection{Teste de escoamento}

Segundo a ISO 6876:2012, um cimento endodôntico não deve apresentar nesse teste um diâmetro inferior a $17 \mathrm{~mm}$. A análise estatística demonstrou que o AH Plus ${ }^{\circledR}$ apresentou o maior valor de média $(39,68 \mathrm{~mm})$, seguido do Sealapex ${ }^{\circledR}(35,73 \mathrm{~mm})$ e pelo Endomethasone $\mathrm{N}^{\circledR}$ $(34,22 \mathrm{~mm})$. O BioRoot ${ }^{\circledR}$ apresentou o menor valor de média para esse teste $(23,81 \mathrm{~mm})$.

Tabela 2 - Valores de média para testes tempo de endurecimento (minutos), radiopacidade (milímetros de Alumínio) e teste de escoamento (milímetros) e desvio padrão (DP) para os diferentes materiais. Letras diferentes indicam diferença estatisticamente significante entre os materiais $(\mathrm{p}<0.05)$.

\begin{tabular}{cccc}
\hline Material & $\begin{array}{c}\text { Tempo de } \\
\text { Endurecimento }\end{array}$ & Radiopacidade & $\begin{array}{c}\text { Teste de } \\
\text { Escoamento }\end{array}$ \\
\hline AH Plus & $1450 \pm 18.01^{\mathrm{a}}$ & $150,23 \pm 8.87^{\mathrm{a}}$ & $39.68 \pm 3.575^{\mathrm{a}}$ \\
\hline Endomethasone & $606.7 \pm 12.66^{\mathrm{b}}$ & $121.85 \pm 16.44^{\mathrm{a}}$ & $34.22 \pm 5.802^{\mathrm{a}}$ \\
\hline Sealapex & $0.0 \pm 0.0^{\mathrm{c}}$ & $134.37 \pm 4.03^{\mathrm{a}}$ & $35.73 \pm 5.498^{\mathrm{a}}$ \\
\hline BioRoot & $255 \pm 15.72^{\mathrm{d}}$ & $138,70 \pm 2,55^{\mathrm{a}}$ & $23.81 \pm 4.628^{\mathrm{b}}$ \\
\hline
\end{tabular}


Figura 1 - Gráficos representativos dos testes de tempo de endurecimento, radiopacidade e escoamento, para os materiais AH Plus ${ }^{\circledR}$, Endomethasone $N^{\circledR}$, Sealapex ${ }^{\circledR}$ e BioRoot RCS $^{\circledR}$. Letras diferentes significam diferença estatisticamente significante entre os materiais $(\mathrm{p}<0,05)$.

Tempo de Endurecimento

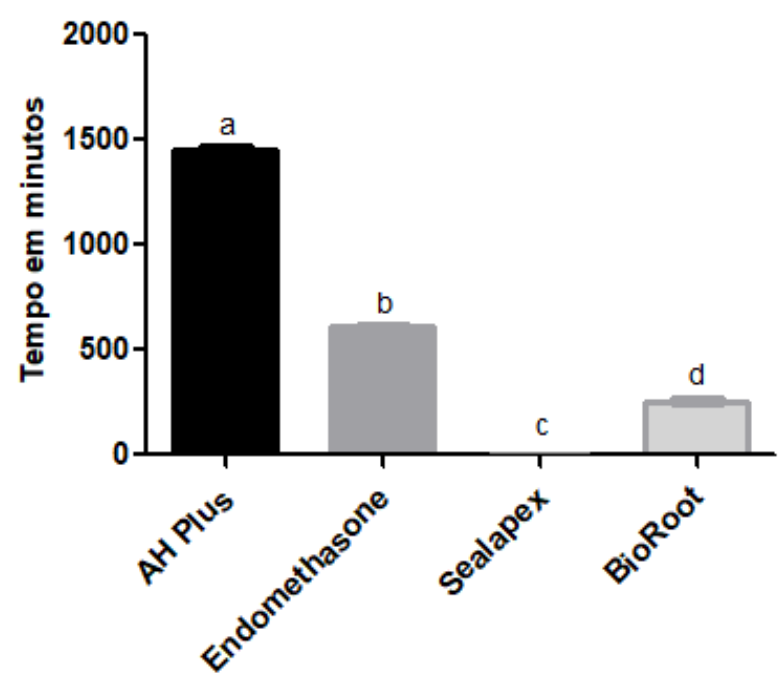

Radiopacidade

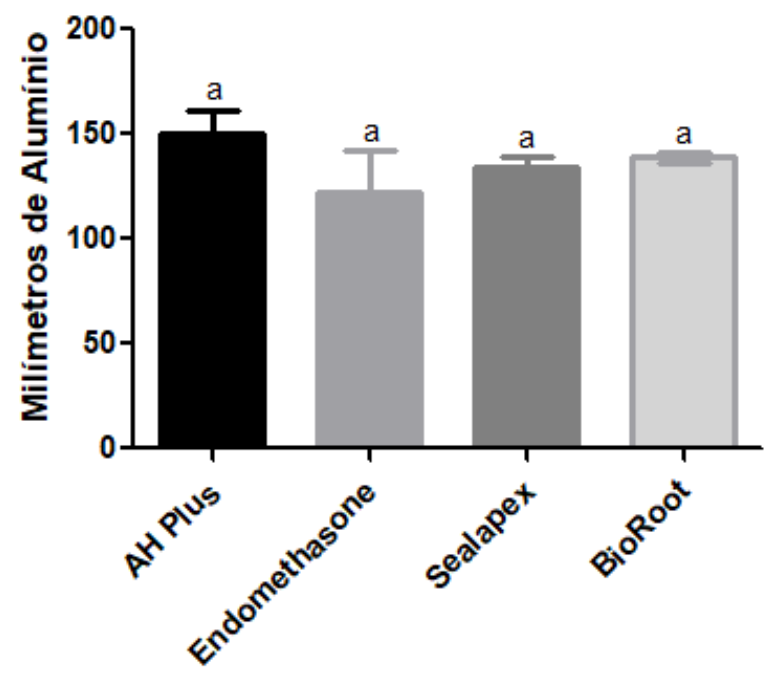

Teste de Escoamento

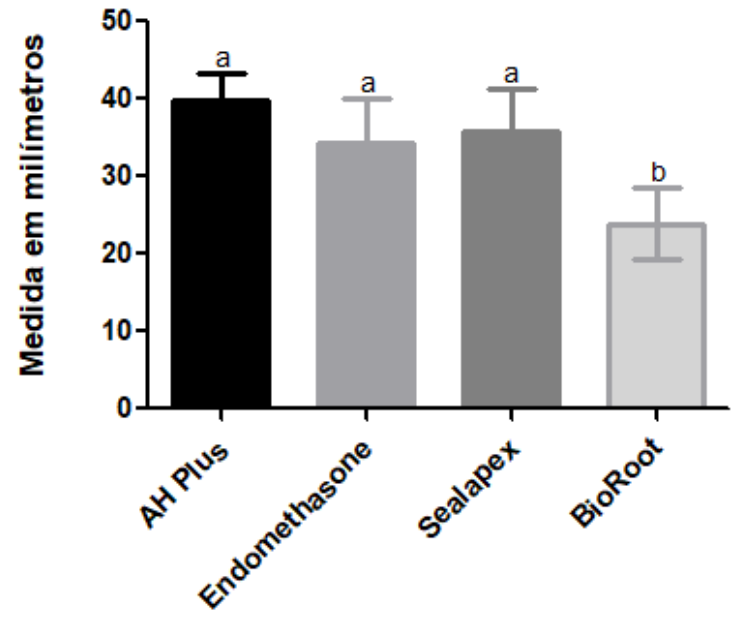




\subsection{Citotoxicidade}

As várias diluições de cada material foram comparadas aos controles negativo e positivo, a fim de avaliar em qual das diluições apresentavam maio viabilidade celular dos linfócitos.

O Endomethasone $\mathrm{N}^{\circledR}$ apresentou a pior viabilidade celular, expressando citotoxicidade nas diluições $(1: 2,1: 4,1: 8,1: 16)(\mathrm{p}<0,05)$. Porém, na diluição de $1: 32$, não apresentou citotoxicidade $(\mathrm{p}>0,05)$.

O Sealapex ${ }^{\circledR}$ apresentou viabilidade celular significantemente menor apenas na diluição de 1:32, quando comparado ao controle negativo $(\mathrm{p}<0,05)$. Nas demais concentrações, não foi observada diferença estatisticamente significante $(\mathrm{p}>0,05)$.

$\mathrm{O}$ AH Plus ${ }^{\circledR}$ e BioRoot ${ }^{\circledR}$ não expressaram citotoxicidade em nenhuma das concentrações avaliadas $(\mathrm{p}>0,05)$.

Figura 2 - Figura representativa da avaliação de viabilidade celular por meio do ensaio do MTT.

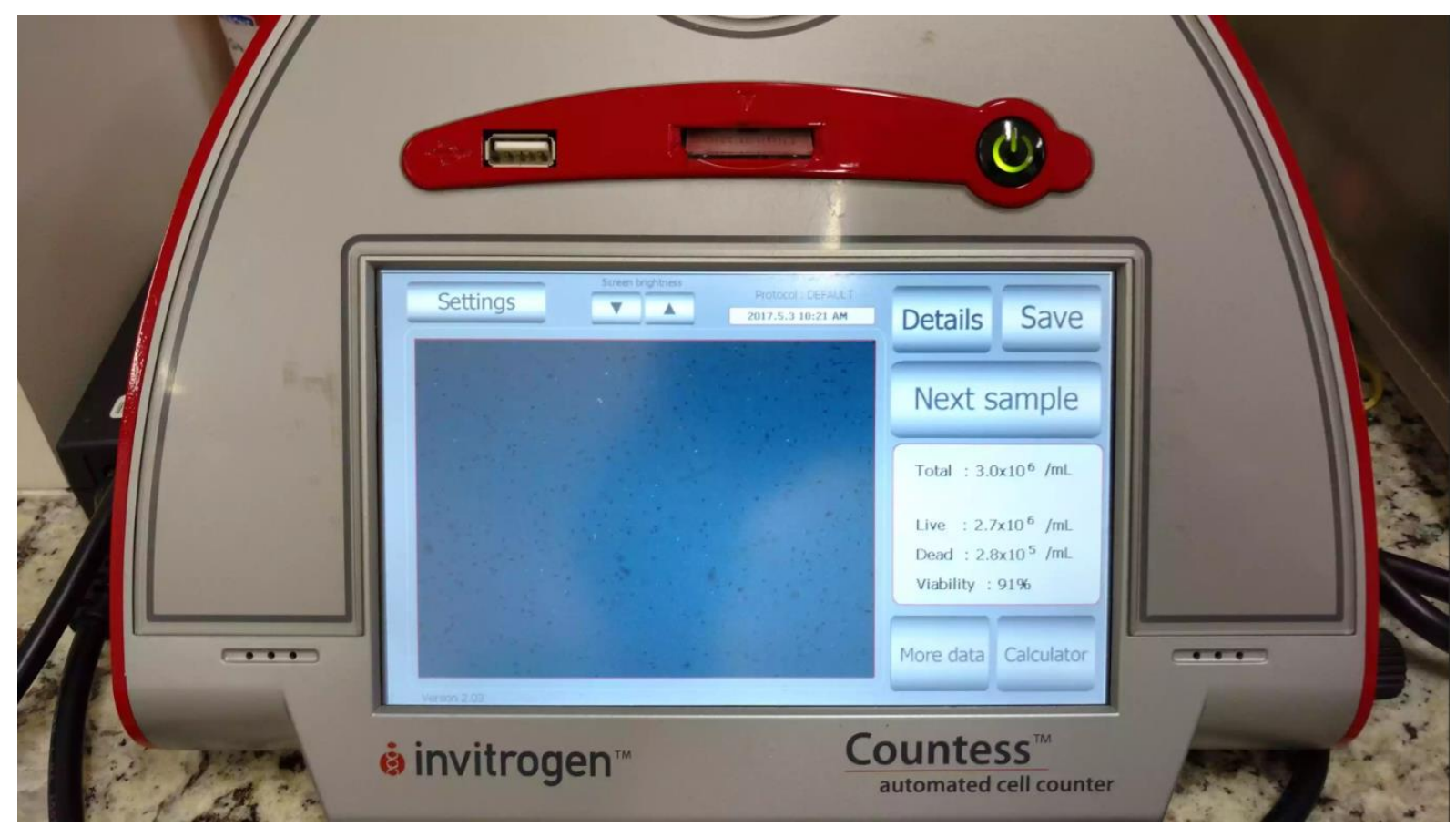


Figura 3 - Gráficos representativos do teste de citotoxicidade por meio de avaliação da viabilidade celular no MTT, para os materiais AH Plus ${ }^{\circledR}$, Sealapex ${ }^{\circledR}$, Endomethasone $\mathrm{N}^{\circledR}$ e BioRoot $\mathrm{RCS}^{\circledR}$, em comparação ao controle positivo $(\mathrm{CP})$ e negativo $(\mathrm{CN})$. Asteriscos indicam diferença estatisticamente significante para cada diluição $(p<0,05)$.
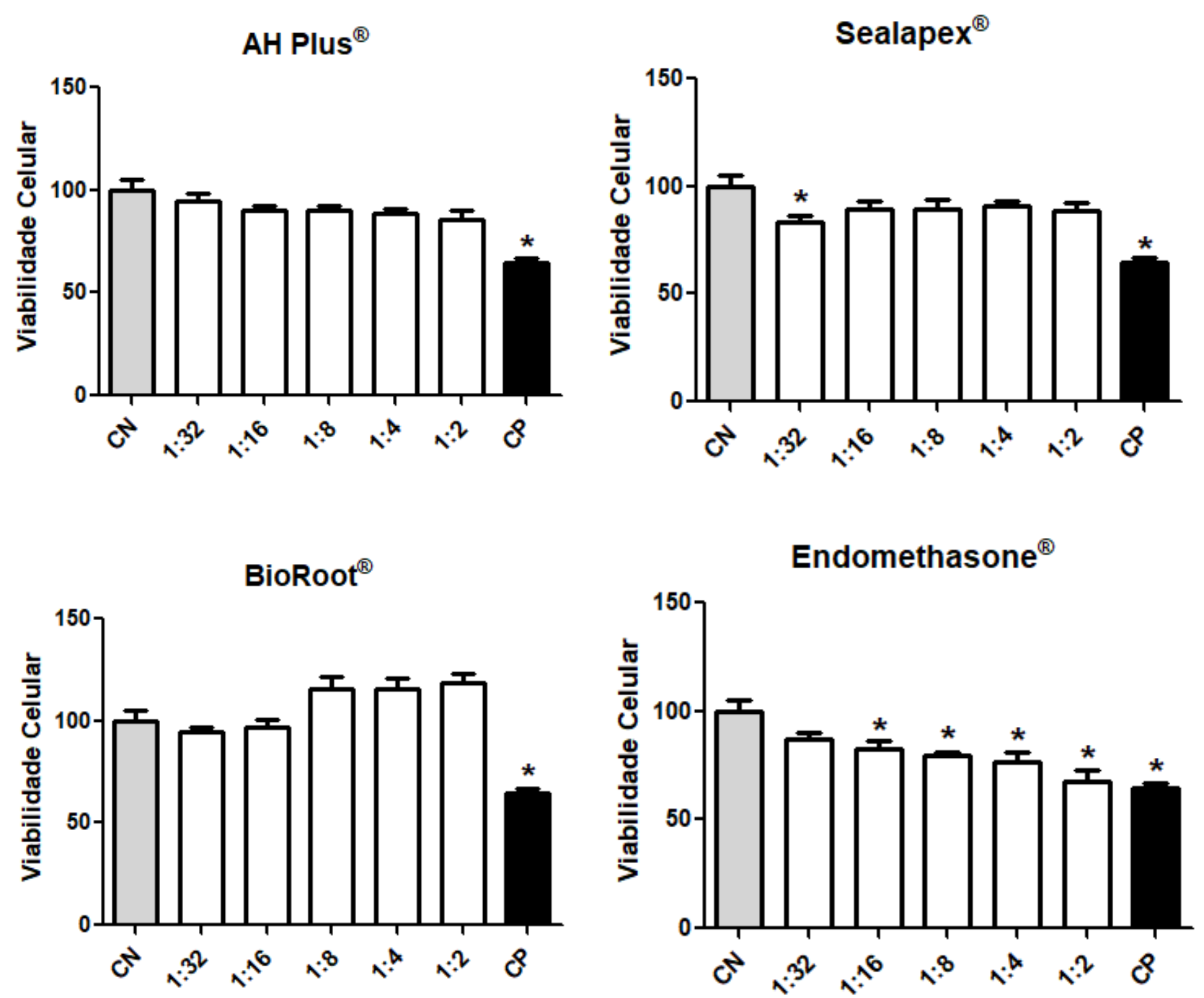
Figura 4 - Gráficos representativos do teste de citotoxicidade por meio de avaliação da viabilidade celular no MTT para os materiais AH Plus ${ }^{\circledR}$, Sealapex ${ }^{\circledR}$, Endomethasone $\mathrm{N}^{\circledR}$ e BioRoot $\mathrm{RCS}^{\circledR}$, em comparação aos controles positivo $(\mathrm{CP})$ e negativo $(\mathrm{CN})$, nas diluições de $1: 2,1: 4,1: 8,1: 16,1: 32$. Letras diferentes indicam diferença estatisticamente significante para cada material $(p<0,05)$.

$1: 2(50 \mathrm{mg} / \mathrm{mL})$

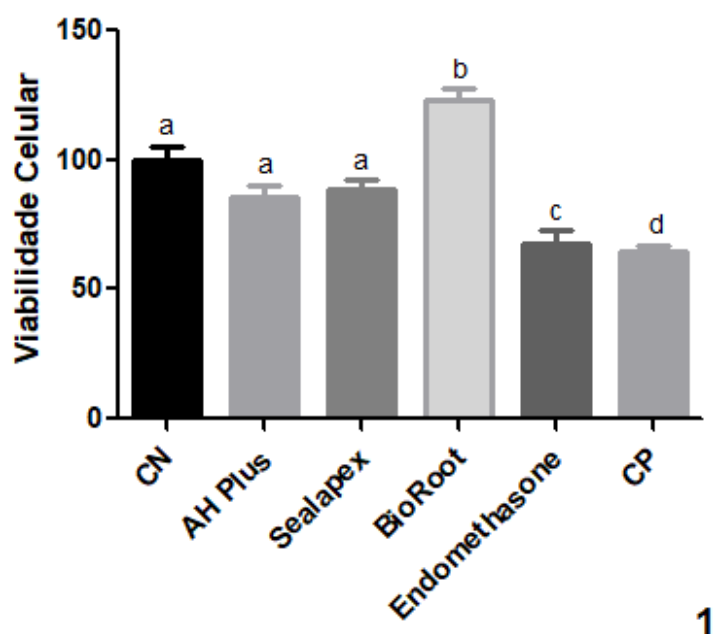

$1: 8(12,5 \mathrm{mg} / \mathrm{mL})$
$1: 4(25 \mathrm{mg} / \mathrm{mL})$

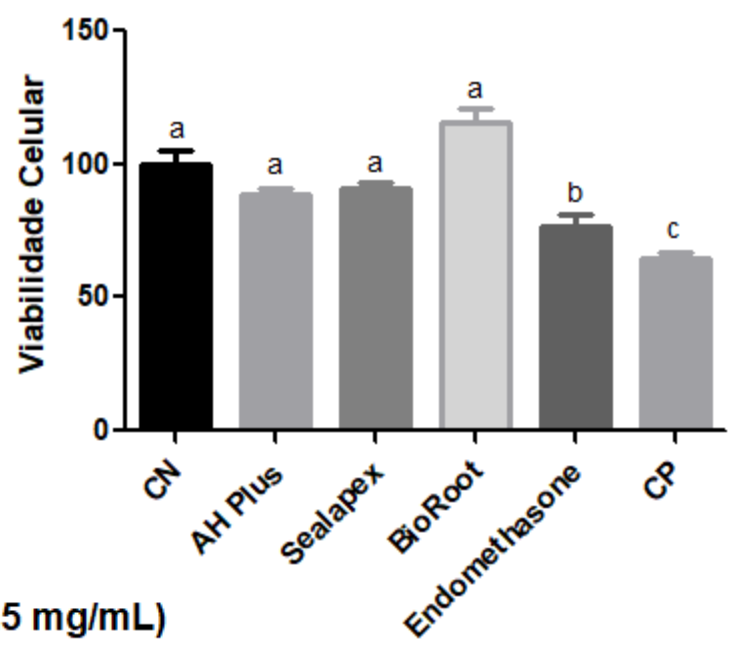

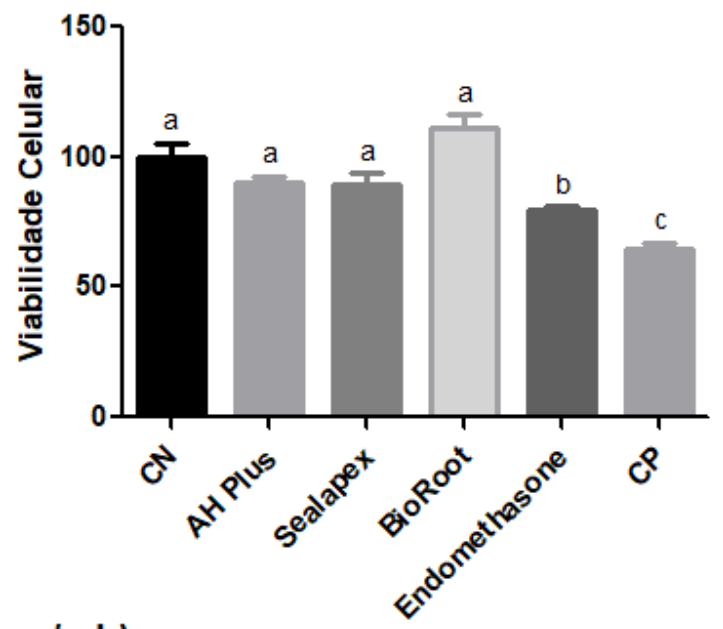

$1: 16(6,25 \mathrm{mg} / \mathrm{mL})$

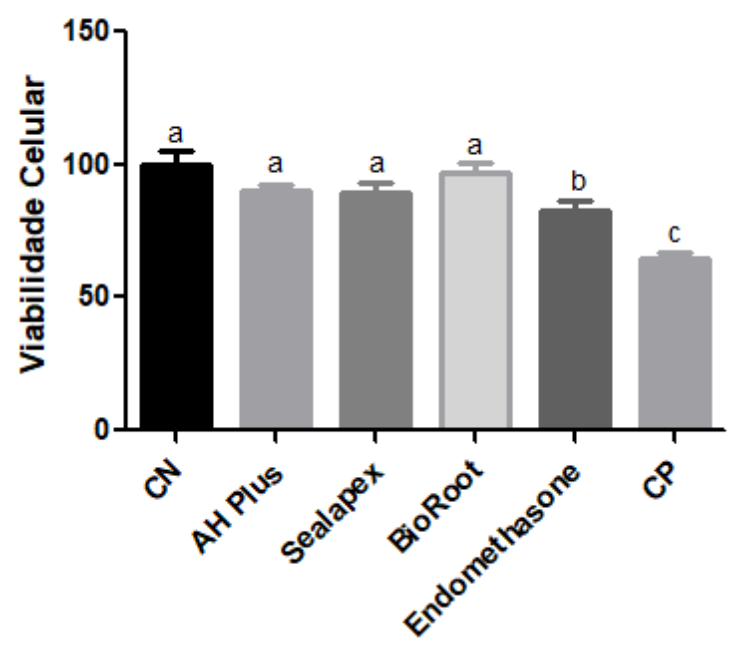

$1: 32(3,125 \mathrm{mg} / \mathrm{mL})$

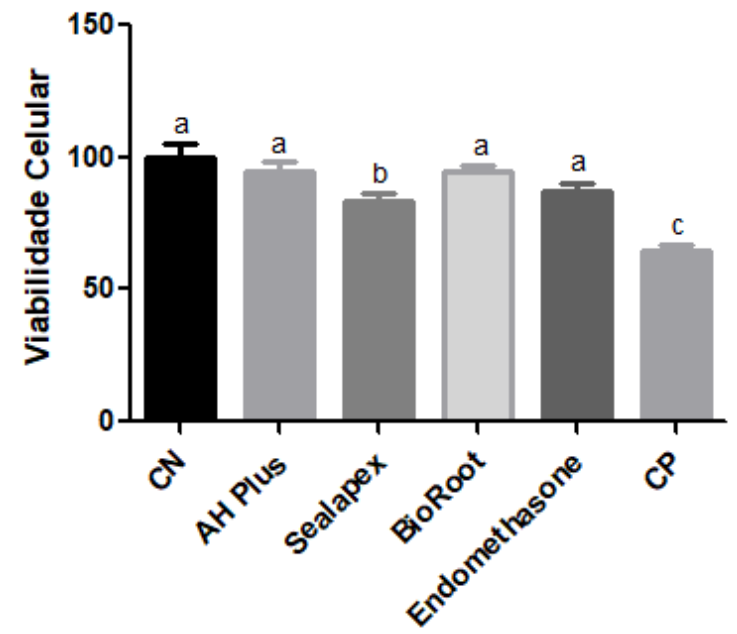


5. Discussãa 



\section{DISCUSSÃO}

As propriedades dos cimentos obturadores de canais radiculares podem ser divididas nas seguintes categorias: físico-químicas, antimicrobianas e biológicas. Quando se estuda as propriedades de um material obturador, é possível estabelecer parâmetros para o desenvolvimento de novos produtos e avaliação daqueles já existentes no comércio específico (Sousa-Neto et al., 1999), visando melhores resultados na prática clínica.

A American Dental Association (ADA) efetivou, em 1983, sob o título de Especificação $\mathrm{n}^{\circ}$ 57, uma série de normas e testes para avaliação das propriedades físico-químicas dos materiais obturadores endodônticos, com a finalidade de promover uniformidade dos resultados, o que levou os pesquisadores a realizarem estes testes com maior critério e rigor científico. Esta especificação determina, para avaliação das propriedades físico-químicas dos materiais obturadores endodônticos, os seguintes testes: escoamento, espessura do filme, tempo de endurecimento, radiopacidade, solubilidade e desintegração e estabilidade dimensional.

A ISO 6876:2012 em sua terceira edição cancela e substitui a segunda edição (ISO 6876: 2001), que foi tecnicamente revisada. As principais modificações são as seguintes:

- Os procedimentos de teste de escoamento, tempo de trabalho e solubilidade foram revistos e foi estabelecido um novo valor-limite;

- O teste para determinar a alteração dimensional foi removido (ISO 6876: 2012).

Os testes físico-químicos realizados neste estudo seguem a especificação $\mathrm{n}^{\circ} 57$ ANSI/ADA (2008) e ISO 6876 (2012), com modificações propostas por Carvalho-Júnior et al., (2007b), seguido por Resende et al. (2009), que sugeriram redução de 80\%, em volume do cimento obturador necessário. Para evitar os efeitos que as variações da umidade e da temperatura poderiam provocar nos resultados dos testes, seguiu-se a determinação da ADA, que preconiza as condições de 23 graus centígrados de temperatura e umidade relativa de $95 \%$.

As normas da Especificação no 57 da ANSI/ADA (2012) exigem que um cimento obturador de canal radicular não deva ter o tempo de endurecimento superior a $10 \%$ daquele determinado pelo fabricante. O valor médio de tempo de endurecimento do cimento AH Plus ${ }^{\circledR}$ informado pelo fabricante é de 24 horas, compatível com o resultado encontrado no presente estudo, de 1450 minutos em média. O Sealapex ${ }^{\circledR}$ não apresentou presa, diferentemente do informado pelo fabricante, que indica uma presa inicial em 60 minutos e final em 24 horas. Para o Endomethasone $\mathrm{N}^{\circledR}$, não há informação fornecida pelo fabricante sobre seu tempo de presa, porém, no presente estudo encontramos um valor médio de 606 minutos. O BioRoot 
$\mathrm{RCS}^{\circledR}$ apresentou uma média de 255 minutos para o tempo de presa, resultado compatível com o relatado pelo fabricante (4 horas).

O tempo de endurecimento dos materiais obturadores depende dos componentes que o constituem, tamanho das partículas, da temperatura ambiente e da umidade relativa (McMichen et al., 2003; Schäfer et al., 2015). O tempo de endurecimento é um teste primário de controle para análise do comportamento estável de um material e é dependente dos compostos dos cimentos, tamanho das partículas, temperatura ambiente e umidade relativa (Ørstavik et al., 2001; Gambarini et al., 2009). Os agentes químicos utilizados para promover a radiopacidade do Endomethasone ${ }^{\circledR}$ (Óxido de chumbo e subnitrato de bismuto) e do AH Plus ${ }^{\circledR}$ (óxido de zircônio e tungstato de cálcio) podem ser responsáveis pelo maior tempo de endurecimentos, uma vez que estes agentes radiopacificantes têm baixa solubilidade em água (Sousa-Neto et al., 2009). O Sealapex ${ }^{\circledR}$ não tomou presa na fase experimental desse estudo (1 semana), o que está de acordo com achados anteriores (Allan et al., 2001; Ingle et al., 2002).

Os resultados evidenciaram que o cimento AH Plus ${ }^{\circledR}$ apresentou os maiores valores de tempo de endurecimento em função de apresentar matrizes poliméricas bisfenol A e bisfenol $\mathrm{B}$, que possuem alto peso molecular, quando comparados com os polímeros de polidimetilsiloxano (Case et al., 2005). A polimerização ocorre pela interação das resinas epóxi com as aminas que atuam como catalisadores da reação, e essa reação é lenta uma vez que conversão dos monômeros em polímeros ocorre de modo gradual (Lin-Gibson et al., 2006). O cimento AH Plus ${ }^{\circledR}$ apresenta em sua formulação dobenzildiamina aminoadamantano e triciclodecanodiamina, que correspondem a aminas ciclo alifáticas e aromáticas (McDermott, 1990). Estes agentes são responsáveis pelo maior tempo de endurecimento da resina (Mark et al., 1986).

$\mathrm{Na}$ análise do teste de radiopacidade, as densidades radiográficas obtidas, em escala de cinza, forneceram a média da densidade radiográfica de cada material. De acordo com a Especificação ${ }^{\circ} 57$ da ANSI/ADA, todo material obturador de canal radicular deve apresentar radiopacidade equivalente ou superior a $3 \mathrm{~mm}$ de alumínio. Ainda, os cimentos obturadores de canais radiculares devem ter radiopacidade suficiente para que se possa distinguir entre os materiais e as estruturas anatômicas adjacentes para facilitar a avaliação da qualidade da obturação, que pode ser somente obtida por meio de exame radiográfico (Carvalho-Júnior et al., 2007).

Os resultados do presente estudo demonstraram que todos os cimentos avaliados apresentaram resultados para a radiopacidade condizentes com o estabelecido pela ANSI/ADA. O maior valor de média para o teste de radiopacidade no presente estudo foi apresentado pelo 
material AH Plus ${ }^{\circledR}$, com valor de 150,23 mmAL. O BioRoot RCS $^{\circledR}$ apresentou um valor médio de 138,70 mmAL e o Sealapex ${ }^{\circledR}$ de 134,37 mmAL. O Endomethasone $\mathrm{N}^{\circledR}$ apresentou a menor média (121,85 mmAL) em comparação aos demais materiais. E quando comparados com a escada de Alumínio utilizada para medir a radiopacidade, o Endomethasone $\mathrm{N}^{\circledR}$ e o BioRoot RCS $^{\circledR}$ corresponderam ao degrau 3 mm de Alumínio; o Sealapex ${ }^{\circledR}$ ao degrau 4 mm Alumínio e o AH Plus ${ }^{\circledR}$ ao degrau $5 \mathrm{~mm}$ Alumínio. Não foi observada diferença estatisticamente significante na radiopacidade de diferentes materiais avaliados $(\mathrm{p}>0,05)$.

Analisando as formulações dos cimentos estudados, observa-se que os cimentos possuem agentes radiopacificadores, compatíveis com substâncias de peso atômico elevado, que determinam a radiopacidade dos cimentos. O cimento $\mathrm{AH}$ Plus ${ }^{\circledR}$ apresenta o óxido de zircônio, óxido de ferro e tungstato de cálcio, que lhe conferiram, no presente estudo, a maior radiopacidade numérica entre os cimentos analisados, estando de acordo com os achados de Duarte et al. (2007), Tanomaru-Filho et al. (2007), Carvalho-Júnior et al. (2007) e Resende et al. (2009). O AH Plus ${ }^{\circledR}$, um cimento à base de resina epóxica, é considerado o padrão ouro entre os cimentos endodônticos devido às suas excelentes propriedades físico-químicas (De Almeida et al., 2000; Kopper et al., 2003; Cintra et al., 2017).

Para o teste de escoamento, a ISO 6872:2012 estabalece como o mínimo de 17mm como valor aceitável de diâmetro do disco formado pelo cimento obturador. O AH Plus ${ }^{\circledR}$ apresentou o maior valor de média para esse teste $(39,68 \mathrm{~mm})$, seguido pelo Sealapex ${ }^{\circledR}(35,73 \mathrm{~mm})$ e, posteriormente, pelo Endomethasone $\mathrm{N}^{\circledR}(34,22 \mathrm{~mm})$. O BioRoot ${ }^{\circledR}$ apresentou o menor valor de média para o teste de escoamento $(23,81 \mathrm{~mm})$. No presente estudo, os valores foram adequados ao mínimo estabelecido pela ISO para todos os cimentos avaliados, bem como podemos relacionar tais resultados com os obtidos por Versiani et al. (2006) e Resende et al. (2009).

O BioRoot RCS $^{\circledR}$ se apresenta como um material bioativo, com a capacidade de nuclear depósitos de apatita carbonatada, devido à sua alta capacidade de liberar íons de cálcio (Siboni et al., 2017). No entanto, esse mesmo material apresenta valores baixos para a radiopacidade, não satisfazendo o uso pelos clínicos, que geralmente utilizam materiais mais radiopacos, como o AH Plus ${ }^{\circledR}$.

A citotoxicidade in vitro de diversos cimentos endodônticos foi investigada em vários estudos (Willershauesen et al., 2013; Cotti et al., 2014; Diomede et al., 2014). Há uma variedade de resultados apontando que a maioria dos cimentos endodônticos são pouco biocompatíveis e expressam alta citotoxicidade quando de sua análise em cultura de células, principalmente quando recém-manipuladas (Gandolfi e Prati 2010; Chang et al., 2014). Dentre as limitações 
da avaliação da citotoxicidade in vitro podemos citar a avaliação de reações celulares, e nem sempre o grau de citotoxicidade revelado para um material determinará a mesma reação nos tecidos, devido à incapacidade de determinar a interação entre estes e o material.

Um processo de inflamação aguda pode ser ocasionado quando estes materiais entram em contato direto com os tecidos conjuntivos apicais, o qual resulta na destruição tecidual, sendo a inflamação mantida por agentes infecciosos, remanescentes de micro-organismos mortos e corpos estranhos (Vidal, 2007).

Os protocolos relacionados aos testes de citotoxicidade foram padronizados pela ISO por meio de um memorando emitido em 1992 pela Food and Drug Administration (FDA 1992), onde é descrita uma série de requisitos a serem seguidos e respeitados durante a realização dos testes in vitro de citotoxicidade de biomateriais. Três categorias de testes são estabelecidas pelas normas ISO 10993-5, sendo elas: testes por extração, teste de contato direto e teste de contato indireto. Optamos por realizar no presente estudo os experimentos por meio de extração, sendo os extratos preparados com os materiais obturadores de canais radiculares recém-manipulados, levando-se em consideração estudos feitos por Spangberg e Pascon (1988), onde enfatizaram a importância do preparo dos biomateriais a serem testados in vitro quanto à sua citotoxicidade, concluindo que este deve ser realizado exatamente como na utilização da clínica diária, expressando resultados mais confiáveis.

A cultura de células é um instrumento de grande importância na avaliação do mecanismo de biocompatibilidade dos materiais dentários, apesar de ter um valor limitado. Para se investigar a resposta biológica de tais materiais, seria necessário avaliar o efeito biológico de cada substância liberada separadamente e em combinação, e ainda, seus efeitos sinérgicos e antagônicos, pois possuem composições químicas complexas e diferentes componentes que são liberados para as áreas circundantes, sendo para isso necessário ser realizado mais de um método laboratorial na avaliação desses vários aspectos (Leirskar e Helgeland, 1981).

Escolhemos para a realização do teste de citotoxicidade no presente estudo células de cultura primária, que são as mais indicadas para os testes de citotoxicidade de materiais endodônticos, sendo elas linfócitos do sangue periférico humano (Huang et al., 2002). Preston et al., em 1987, descreveram um protocolo para padronização do cultivo dessas células para a realização de experimentos in vitro. Podemos destacar como vantagens do uso de linfócitos em laboratórios a sua estabilidade de cariótipo, não possuíram grandes variações de duração de ciclo celular, estarem disponíveis em grandes quantidades em pequenas amostras do sangue periférico, por todo o corpo, e circularem em todos os tecidos (Evans e O'Riordan, 1975; Preston et al., 1987), além de serem células comuns aos tecidos periodontais e periapicais. 
O ensaio do MTT foi o teste de escolha para o presente estudo, descrito primeiramente por Mosmann em 1983. Já que a maioria das substâncias liberadas pelos materiais estudados são hidrófilas e susceptíveis à liberação de componentes iônicos, podendo, dessa forma, interferir na atividade de enzimas intracelulares e influenciar na permeabilidade da membrana celular. Tal método foi desenvolvido como uma alternativa não radioativa ao método de incorporação de timidina ao DNA (Mosmann, 1983), e é amplamente utilizado para avaliação da citotoxicidade de diferentes compostos in vitro, utilizando tanto linhagens de células primárias como células imortalizadas (Ho et al., 2012). Esse método de avaliação da citotoxicidade tem como vantagens a rapidez e a precisão, não requerendo radioisótopos (átomos que liberam radiação).

Ao meio de cultivo celular incubado é adicionado o reagente do MTT, 3-(4,5dimetiltiazol-2il) -2-5-difenil-2H tetrazolato de bromo, onde por meio da redução, as células metabolicamente ativas são convertidas do reagente de MTT em formazan, que possui coloração arroxeada, com uma absorção próxima de 570nm. O formazan formado necessita ser solubilizado antes da leitura, pois é insolúvel e se precipita no poço, sendo também depositado no meio e na superfície celular. Alguns parâmetros como concentração de MTT, período de incubação, número de células viáveis e seu estado metabólico é dependente da quantidade de sinal gerada (Berridge e Tan, 1993; Berridge, Herst e Tan, 2005).

A fim de observar a intensidade de eventos relacionados à inflamação aguda, que se dá em torno de 24-48 horas, foi definido o período experimental de 20 horas para esse estudo. Nas primeiras horas após a agressão, o sistema complemento atua por meio de uma defesa inata não induzida e do processo inflamatório, tendo a formação de compostos vasoativos, reconhecimento e fagocitose por macrófagos residentes e liberação de mediadores químicos. Alterações vasculares e a migração de células inflamatórias ocorrem para o local da agressão, especialmente neutrófilos, apresentando atividade fagocitária e podendo intensificar a resposta inflamatória pela liberação de enzimas, mediadores químicos e radicais tóxicos (Pereira; Bogliolo 2009; Siqueira, 2001; Siqueira 2001b; Montenegro e Facchio 2004; Consolaro 2015). Linfócitos e plasmócitos são encontrados mais prevalentemente no infiltrado inflamatório, relacionando-se com as respostas imunes de base celular e de síntese de anticorpos (Pereira e Bogliolo, 2009).

Na região apical e periapical, a morte dos linfócitos é focal e restrita, não apresentando efeito significativo se tivermos como base o contexto geral do corpo. Porém, se pensarmos no efeito local, pode favorecer a anacorese, processo pelo qual as bactérias circundantes são atraídas para a área previamente inflamada, dando origem a um foco infeccioso secundário. 
Resíduos de materiais obturadores são atrativos para ocorrência desse processo (Aboudharam et al., 2000; Dezan Junior, 2001).

Silva et al., em 2017 relataram que quanto mais diluído o cimento endodôntico, menor a sua citotoxicidade. A indicação de uma boa resposta clínica é dada pela ausência de efeito citotóxico, porém a presença de um efeito citotóxico in vitro não garante que o material é tóxico quando aplicado in vivo (Martins et al., 2013).

Cohen et al. (2000), Tai et al. (2002) e Ozorio (2012) apontaram o AH Plus ${ }^{\circledR}$ como sendo um material citotóxico, possivelmente em associação com o fato de ser um material à base de resina epóxica, que libera Bisfenol-A, um componente mutagênico e citotóxico (Spangberg et al., 1993; Cohen et al., 2000; Mandal et al., 2014).

Em nosso estudo, o AH Plus ${ }^{\circledR}$ apresentou resultados próximos ao controle negativo. Não apresentou níveis significantes de citotoxicidade, sendo que podemos observar um aparente contraste com o que encontramos em outros estudos anteriores (Zoufan et al., 2011; Borges et al., 2012; Silva et al., 2013; Kim et al., 2014; Candeiro et al., 2015; Lin et al., 2015; Zhou et al., 2015; Rodríguez-Lozano et al., 2017), que demonstraram algum nível de citotoxicidade para esses cimentos.

Quando comparado aos demais cimentos resinosos, o AH Plus ${ }^{\circledR}$ libera pouca quantidade de formaldeído. Diante disso, Cohen et al., em 2000, sugeriram que sua citotoxicidade se deve principalmente a resina epóxica presente na sua formulação. Essa informação foi confirmada por Huang et al. (2005), quando testaram as duas pastas do AH Plus separadamente e confirmaram maior citotoxicidade da pasta A, que contem resina epóxica. Huang et al. (2005) evidenciaram que além de serem citotóxicos, os cimentos à base de resina epóxica podem estimular a cicloxigenase-2 (COX-2), ativando o processo inflamatório. A cicloxigenase-2 (COX-2) é a enzima responsável pela síntese de prostaglandinas nos locais de inflamação (Huang et al., 2005).

Miletić et al., em 2003, estudaram a citotoxicidade e a mutagenicidade in vitro dos cimentos AH Plus ${ }^{\circledR}$ e AH $26^{\circledR}$. O experimento foi realizado em células V79 de hamster chinês e a viabilidade celular foi determinada pela contagem de células, após a incubação dos eluatos. Concluíram que não houve citotoxicidade para os cimentos testados $\mathrm{AH}$ Plus ${ }^{\circledR}$ e $\mathrm{AH} 26^{\circledR} \mathrm{em}$ linfócitos humanos, em condições in vitro controladas.

$\mathrm{O}$ AH Plus ${ }^{\circledR}$ é uma modificação do cimento $\mathrm{AH} 26^{\circledR}$, e a principal diferença entre eles, segundo o fabricante, foi a retirada de formaldeído da formulação do $\mathrm{AH} 26^{\circledR}$, o que deu origem ao AH Plus ${ }^{\circledR}$ (Hargreaves e Cohen, 2011). Estudos experimentais em humanos e animais 
demonstraram que o formaldeído inalado provoca genotoxicidade, citotoxicidade e câncer (Costa 2011).

$\mathrm{Na}$ formulação do $\mathrm{AH}$ Plus ${ }^{\circledR} \mathrm{o}$ fabricante não inclui o formaldeído, porém um estudo realizado por Ozorio, em 2012, avaliou a quantidade de formaldeído liberado por alguns cimentos endodônticos, entre eles o $\mathrm{AH} \mathrm{Plus}^{\circledR}$ e teve como resultado que o mesmo liberou formaldeído. Em seu estudo, observou que o cimento que mais liberou formaldeído foi o Sealer $26^{\circledR}$ durante o tempo de espatulação $(7,40 \mathrm{mg} . \mathrm{L}-1)$, seguido do AH Plus ${ }^{\circledR}$ que liberou 4,44 mg.L -1 durante seu tempo de presa. Estes valores estão muito acima do limite máximo de 0,1 ppm/15M recomendado pelo National Institute for Occupational Safety and Health (NIOSH) (INCA, 2011), porém dentro do limite máximo permitido de exposição contínua, que é de $5 \mathrm{ppm}$, sendo que, nos casos de pico, a concentração máxima deve ser de 10ppm segundo a Occupational Health and Safety Assessment Services (OSHA) (2011).

Konjhodzic-Prcic et al., em 2015, também avaliaram a biocompatibilidade de cimentos endodônticos de diferentes bases $\left(\right.$ GuttaFlow $^{\circledR}$, AH Plus $^{\circledR}$, Apexit $^{\circledR}$ e Endorez $^{\circledR}$ ) em fibroblastos de ratos (L929), em espectrômetro. Os cimentos foram avaliados quando da sua mistura, em 24, 48 horas e 7 dias. A biocompatibilidade foi determinada pelo ensaio de MTT, e os níveis de absorção pelo espectrômetro. Como resultados, obtiveram que os cimentos Apexit Plus ${ }^{\circledR}$, GuttaFlow $^{\circledR}$ e AH Plus ${ }^{\circledR}$ demonstraram a menor citotoxicidade em todos os períodos avaliados, sendo esses três materiais considerados biocompatíveis. Esses resultados são concordantes com o presente estudo, onde o AH Plus ${ }^{\circledR}$ também apresentou ótimos níveis de viabilidade celular, não expressando citotoxicidade em nenhuma das diluições avaliadas.

Segundo Eldeniz et al. (2016) o cimento endodôntico AH Plus ${ }^{\circledR}$ apresentou citotoxicidade 10 vezes maior se comparado com o BioRoot $\mathrm{RCS}^{\circledR}$. Por outro lado, em um estudo animal com periodontite apical induzida, os tecidos periapicais adjacentes ao canal radicular preenchidos com resina epóxica apresentaram a menor inflamação em comparação a outros cimentos obturadores testados (à base de óxido de zinco e eugenol e silicone) (Dammaschke et al., 2006; Jung et al., 2018). Essa diferença de citotoxicidade expressa entre AH Plus ${ }^{\circledR}$ e BioRoot RCS $^{\circledR}$ não foi observada em nosso estudo, que foi realizado em cultura de células primárias de linfócitos do sangue periférico humano. Ambos materiais não apresentaram diferença estatisticamente significante $(p>0,05)$, indicando adequada viabilidade celular.

Alguns autores indicam a associação de corticóides aos cimentos com a finalidade de reduzir a reação inflamatória frente ao contato com o material obturador e para que a diferenciação dos tecidos duros periapicais ocorra de forma mais rápida, tendo em vista que 
grande parte das reações inflamatórias que ocorrem após o tratamento endodôntico são agravadas pela natureza e características biológicas do material (Erausquin e Muruzabal, 1967). Dessa forma, a hidrocortisona foi acrescida à formulação do Endomethasone N®. Também, outra mudança que se deu na formulação desse material foi a remoção do paraformaldeído, presente na formulação do Endomethasone ${ }^{\circledR}$ inicial (Gomes et al., 2004).

Em 1998, Savioli analisou várias propriedades de alguns cimentos endodônticos, entre eles o Endomethasone $\mathrm{N}^{\circledR}$, e pode observar que este apresenta baixos valores de solubilidade e pouca perda de massa, sem que houvesse partículas em suspensão, ressaltando que a baixa solubilidade é uma característica favorável dos materiais obturadores devido à desejada estabilidade intra-canal. Ainda, em um estudo realizado em 1999 por Leonardo et al. investigou e comparou a liberação de formaldeído ente o Endomethasone ${ }^{\circledR}$ e o AH Plus ${ }^{\circledR}$, concluindo que Endomethasone ${ }^{\circledR}$ tinha maior liberação de formaldeído.

$\mathrm{O}$ Endomethasone $\mathrm{N}^{\circledR}$ no presente estudo mostrou citotoxicidade em quase todas as diluições, se comparado ao controle positivo, apresentando-se como o mais citotóxico entre os materiais avaliados. Estudos prévios realizados com fibroblastos 3T3 e células humanas do ligamento periodontal demonstram que esse material inibiu fortemente a atividade mitocondrial durante as primeiras 24 horas (Gerosa et al., em 1995; Schwarze et al., 2002). Esta constatação foi provavelmente devido à liberação de eugenol necessário para a manipulação do Endomethasone N® (ISO 7405: 2008; Gulati et al., 1991; Schwarze et al., 2002) e também à hidrocortisona e o timol também presentes neste cimento, que são substâncias reconhecidamente citotóxicas (Gerosa et al., 1995; Badole et al., 2013).

Huang et al., em 2002 realizaram um estudo com células primárias do ligamento periodontal e linhagem de células de hamsters (V79), onde compararam a citotoxicidade de cinco cimentos obturadores de canais radiculares, entre eles o Endomethasone $\mathrm{N}^{\circledR}$ e o AH Plus ${ }^{\circledR}$, e obtiveram como resultado que o Endomethasone $\mathrm{N}^{\circledR}$ teve o maior grau de citotoxicidade, quando comparados aos outros cimentos. Os resultados encontrados por esses autores são semelhantes aos que encontramos em nosso estudo.

Em 2013, Silva, Santos e Zaia estudaram os efeitos citotóxicos de oito cimentos endodônticos $\left(A H\right.$ Plus ${ }^{\circledR}$, Epiphany ${ }^{\circledR}$, Endomethasone $N^{\circledR}$, EndoREZ ${ }^{\circledR}$, MTA Fillapex ${ }^{\circledR}$, Pulp Canal Sealer EWT ${ }^{\circledR}$, RoekoSeal ${ }^{\circledR}$ e Sealapex ${ }^{\circledR}$ ) a longo prazo. Foram utilizadas células 3T3 (fibroblastos) em contato com as amostras dos cimentos recém-manipulados e observados os efeitos dos cimentos por 5 semanas seguidas. A citotoxicidade de cada material foi avaliada pelo ensaio do MTT. O Endomethasone $\mathrm{N}^{\circledR}$ apresentou viabilidade celular baixa até a segunda semana. No entanto, após esse período, apresentou boa viabilidade celular. Em nosso estudo, 
pudemos observar que o Endomethasone $\mathrm{N}^{\circledR}$ apresentou citotoxicidade nas diluições de 1:2; 1:4; 1:8; 1:16; porém na diluição de 1:32 não expressou diferença estatisticamente significante, conforme o observado nos estudos anteriores citados.

$\mathrm{O}$ Endomethasone $\mathrm{N}^{\circledR}$ é um material com boa atividade antimicrobiana, devido à presença de eugenol e timol, porém esses componentes também aumentam a toxicidade do material, provocando danos aos tecidos periapicais, o que não compensa os benefícios das propriedades antibacterianas do material (Gomes et al., 2004).

$\mathrm{O}$ cimento obturador BioRoot $\mathrm{RCS}^{\circledR}$, composto à base de silicato tricálcio com apresentação pó/líquido, é comercializado desde fevereiro de 2015 e recomendado para a técnica de obturação de cone único ou condensação lateral fria. O BioRoot $\operatorname{RCS}^{\circledR}$ tem sido citado em testes in vitro como indutor de fatores de crescimento angiogênicos e osteogênicos por células do ligamento periodontal humano (Camps et al., 2015). Além disso, possui uma menor citotoxicidade que os materiais obturadores de canais radiculares convencionais, podendo induzir uma maior deposição de tecido mineralizado (Dimitrova-Nakov et al. 2015, Prüllage et al. 2016), possuindo também atividade antimicrobiana (Arias-Moliz \& Camilleri, 2016).

De acordo com estudos recentes, o BioRoot $\operatorname{RCS}^{\circledR}$ apresentou excelente biocompatibilidade em todas as concentrações dos extratos tanto no material fresco quanto depois de sua presa. No contato direto com as células, o BioRoot $\operatorname{RCS}^{\circledR}$ não foi citotóxico e não afetou a viabilidade celular e morfologia. $\mathrm{O}$ crescimento celular não foi adversamente afetado (Camps et al., 2015; Dimitrova-Nakov et al., 2015; Eldeniz et al., 2016; Collado-González et al., 2017). No presente estudo, o BioRoot $\operatorname{RCS}^{\circledR}$ foi mantido em contato com a cultura de linfócitos por meio do eluato de solução. Dessa forma, em diferentes diluições, esse material não expressou níveis significantes de citotoxicidade.

Em testes ex vivo, o BioRoot $\operatorname{RCS}^{\circledR}$ demonstrou melhores resultados que os outros cimentos à base de resina epóxica ou metacrilato (Eldeniz et al., 2016) ou à base de óxido de zinco e eugenol (Camps et al., 2015; Dimitrova-Nakov et al., 2015) e também melhor que outros cimentos à base de silicato de cálcio (Eldeniz et al., 2016; Collado-González et al., 2017). Em comparação aos demais materiais em nosso estudo, tanto o BioRoot ${ }^{\circledR} \operatorname{como}_{\text {o }}$ AH Plus ${ }^{\circledR}$ apresentaram os melhores níveis de viabilidade celular, indicando grande potencial de escolha clínica desses materiais obturadores, com base apenas na citotoxicidade.

De acordo com Schafer et al. (2003) e Desai et al. (2009), o Sealapex ${ }^{\circledR}$ demonstrou uma perda significante de massa quando submetido ao teste de solubilidade recomendado pela ISO 6876 (2001), com alta solubilidade nos fluidos teciduais. Por outro lado, o Sealapex ${ }^{\circledR}$ 
demonstrou boas respostas no reparo tecidual (Sipert et al., 2005; Desai et al., 2009; GomesFilho et al., 2011; Silva et al., 2017). Esses resultados podem ser atribuídos à dissolução de ions cálcio e hidroxila, que aumenta o $\mathrm{pH}$ da região periapical, favorecendo o reparo, exercendo atividade antimicrobiana, promovendo a degradação e inativação de lipopolisacarídeos bacteriano (Willershausen et al., 2011). Além disso, induz o selamento biológico com deposição de tecido mineralizado no forame apical e está associado com processos de reparo favoráveis, induzindo a formação de tecido mineralizado e agindo no controle da reabsorção radicular inflamatória (Leonardo et al., 1997; McMichen et al., 2003; Sipert et al., 2005; Desai e Chandler, 2009; Gomes-Filho et al., 2011).

No estudo de Chang et al. (2010) foi notada retração das células (fibroblastos), marcadas por um aumento do espaço intercelular, após a exposição das mesmas ao cimento endodôntico Sealapex ${ }^{\circledR}$.

Teixeira et al. (2017) avaliaram por meio de fibroblastos gengivais humanos vários grupos de cimentos endodônticos (AH Plus ${ }^{\circledR}+$ cones de guta-percha (GPC); Sealapex $^{\circledR}+$ GPC; MTA Fillapex ${ }^{\circledR}+$ GPC e Endofill ${ }^{\circledR}+$ GPC). Se comparado ao presente estudo, Teixeira et al. observaram também que o $\mathrm{AH}$ Plus $^{\circledR}$ e o Sealapex ${ }^{\circledR}$ demonstraram bons resultados quanto à citotoxicidade, o que se relaciona com achados prévios na literatura (Leonardo et al., 1997; Chang et al., 2010; Gomes-Filho et al., 2011; Silva et al., 2012).

A citotoxicidade pode estar relacionada com o estresse, lesões reversíveis e irreversíveis das células que antecedem a necrose, nas quais há grande liberação de mediadores e proteínas livres (Consolaro, 2015). Materiais com potencial citotóxico podem estar associados com a dor pós-operatória em tratamentos endodônticos. Após a agressão celular ocorre liberação e ativação de mediadores químicos da resposta inflamatória, como a histamina, bradicinina e prostaglandinas, sendo está última associada ao processo de hiperalgesia, ou seja, a sensibilização das fibras nervosas sensitivas, responsável pela dor (Seymour e Walton, 1984). Para o bem-estar dos pacientes é fundamental a utilização de materiais que apresentem biocompatibilidade e preferencialmente ausência de citotoxicidade. Além disso, os testes realizados no presente estudo não permitem inferir a respeito de mutagenicidade e carcinogenicidade, mas estas propriedades devem ser avaliadas em estudos adicionais.

Para o uso clínico, devemos optar sempre pelo material que apresente melhor biocompatibilidade e ausência de citotoxicidade, mutagenicidade ou carcinogenicidade. No presente estudo, os melhores resultados com relação à citotoxicidade foram observados para o AH Plus ${ }^{\circledR}$ e BioRoot RCS ${ }^{\circledR}$. Também, os materiais devem apresentar adequadas propriedades físico-químicas, permitindo adequado desempenho clínico. Todos os materiais analisados no 
presente estudo (AH Plus ${ }^{\circledR}$, BioRoot RCS $^{\circledR}$, Endomethasone $\mathrm{N}^{\circledR}$ e Sealapex ${ }^{\circledR}$ ) apresentaram bons resultados quanto ao endurecimento, radiopacidade e escoamento. Estudos adicionais são necessários, uma vez que o material obturador de canais radiculares ideal ainda não foi estabelecido. 



\section{Canclusãa}





\section{CONCLUSÃO}

Considerando as condições específicas deste trabalho, com base na metodologia empregada e nos resultados obtidos, pode-se concluir que:

$\checkmark$ AH Plus ${ }^{\circledR}$, Endomethasone $\mathrm{N}^{\circledR}$, Sealapex ${ }^{\circledR}$ e BioRoot RCS $^{\circledR}$ atenderam aos parâmetros estabelecidos pela ANSI/ADA quanto aos testes de radiopacidade e escoamento;

$\checkmark$ Sealapex ${ }^{\circledR}$ não apresentou tempo de endurecimento, não estando de acordo com a especificação ANSI/ADA; AH Plus ${ }^{\circledR}$, Endomethasone $\mathrm{N}^{\circledR}$ e BioRoot RCS $^{\circledR}$ se adequaram aos valores estabelecidos;

$\checkmark$ Endomethasone $\mathrm{N}^{\circledR}$ demonstrou características de citotoxicidade sobre os linfócitos nas diferentes concentrações, sendo o mais citotóxico entre os materiais estudados;

$\checkmark$ AH Plus ${ }^{\circledR}$, Sealapex ${ }^{\circledR}$ e BioRoot RCS $^{\circledR}$ apresentaram viabilidade celular em níveis aceitáveis. 

Referências 



\section{REFERÊNCIAS}

ABC do câncer: abordagens básicas para o controle do câncer / Instituto Nacional de Câncer. Rio de Janeiro: Inca, 2011.

Aboudharam G, Lascola B, Raoult D, Drancourt M. Detection of Coxiella burnetii DNA in dental pulp during experimental bacteremia. Microb Pathog. 2000 Apr;28(4):249-54.

Al-Haddad A, Che Ab Aziz ZA. Bioceramic-Based Root Canal Sealers: A Review. Int J Biomater. 2016;2016:9753210.

Al-Hiyasat AS, Tayyar M, Darmani H. Cytotoxicity evaluation of various resin-based root canal sealers. Int Endod J. 2010 Feb;43(2):148-53.

Allan NA, Walton RC, Schaeffer MA. Setting times for endodontic sealers under clinical usage and in vitro condition. J Endod. 2001;27:421-3.

American Dental Association Specification $\mathrm{n}^{\circ} 57$ for Endodontic filling materials. 2000, Washington: The Association.

Anusavice JK, Shen C, Rawls RH. Philips Materiais Dentários - Tradução Roberto Braga. 12a edição - Rio de Janeiro. Elsevier; 2013. Cap. 8, p.160-89.

Anusavice K, Shen C, Rawis H. Phillips Materiais Dentários. Tradução Roberta Braga. 12a edição - Rio de Janeiro. Elsevier, 2013. 8:160-89.

Ashraf H, Moradimajd N, Mozayeni MA, Dianat O, Mahjour F, Yadegari Z. Cytotoxicity evaluation of three resin-based sealers on na L929 cell line. Dent Res J (Isfahan). 2012 Sep;9(5):549-53.

Augsburger RA, Peters DD. Radiographic evaluation of extruded obturation materials. J Endod. 1990 Oct;16(10):492-7.

Badole GP, Warhadpande MM, Meshram GK, Bahadure RN, Tawani SG, Tawani G, Badole SG. A comparative evaluation of cytotoxicity of root canal sealers: an in vitro study. Restor Dent Endod. 2013 Nov;3894):204-9.

Badole GP, Warhadpande MM, Meshram Gk, Bahadure RN, Tawani SG, Tawani G, Badole SG. A comparative evaluation of cytotoxicity of root canal sealers: an in vitro study. Restor Dent Endod. 2013 Nov;38(4):204-9.

Baraba A, Zelježić D, Kopjar N, Mladinić M, Anić I, Miletić I. Evaluation of cytotoxic and genotoxic effects of two resin-based root-canal sealers and their components on human leucocytes in vitro. Int Endod J. 2011 Jul;44(7):652-61.

Baraba A, Zelježić D, Kopjar N, Mladinić M, Anić I, Miletić I. Evaluation of cytotoxic and genotoxic effects of two resin-based root-canal sealers and their components on human leucocytes in vitro. Int Endod J. 2011 Jul;44(7):652-61.

Bernáth M, Szabó J. Tissue reaction initiated by different sealers. Int Endod J. 2003 Apr;36(4):256-61. 
Berridge MV, Herst PM, Tan AS. Tetrazolium dyes as tools in cell biology: new insights into their cellular reduction. Biotechnol Annu Rev. 2005;11:127-52.

Berridge MV, Tan AS. Characterization of the cellular reduction of 3-(4,5-dimethyltiazol-2yl)-2,5-diphenyltetrazolium bromide (MTT): subcellular localization, substrate dependence and involvement of mitochondrial electron transport in MTT reduction. Arch Biochem Biophys. 1993 Jun;303(2):474-82.

Bin CV, Valera MC, Camargo SE, Rabelo SB, Silva GO, Balducci I, Camargo CH. Cytotoxicity and genotoxicity of root canal sealers based on mineral trioxide aggregate. J Endod. 2012 Apr;38(4):495-500.

Borges RP, Sousa-Neto MD, Versiani MA, et al. Changes in the surface of four calcium silicatecontaining endodontic materials and an epoxy resin-based sealer after a solubility test. Int Endod J. 2012 May;45(5):419-28.

Camargo CHR, Camargo SEA, Valera MC, Hiller K, Schmalz G, Schweikl H. The induction of cytotoxicity, oxidative stress, and genotoxicity by root canal sealers in mammalian cells. Oral Surg Oral Med Oral Pathol Oral Radiol Endod 2009; 108:952-960.

Camps J, Jeanneau C, El Ayachi I, Laurent P, About I. Bioactivity of a calcium silicate-based endodontic cement (BioRoot RCS): interaction with human periodontal ligament cells in vitro. J Endod. 2015 41:1469-1473.

Candeiro GT, Correia FC, Duarte MA, Ribeiro-Siqueira DC, Gavini G. Evaluation of radiopacity, $\mathrm{pH}$, release of calcium ions, and flow of a bioceramic root canal sealer. J Endod. 2012 Jun;38(6):842-5.

Candeiro GT, Moura-Netto C, D'Almeida-Couto RS, et al. Cytotoxicity, genotoxicity and antibacterial effectiveness of a bioceramic endodontic sealer. Int Endod J. 2015 Aug 17.

Canova GC, Taveira LAA, Dezan-Junior E, Nishiyama CK, Spalding M. Estudo do poder flogógeno de quatro cimentos obturadores de canais radiculares por meio do teste edemogênico. Rev Fac Odontol Bauru 2002;10(3):128-33.

Carvalho-Junior JR, Correr-Sobrinho L, Correr AB, Sinhoreti MA, Consani S, Sousa-Neto MD. Solubility and dimensional change after setting of root canal sealers: a proposal for smaller dimensions of test samples. J Endod. 2007 Sep;33(9):1110-6.

Carvalho-Junior JR, Correr-Sobrinho L, Correr AB, Sinhoreti MA, Consani S, Sousa-Neto MD. Radiopacity of root filling materials using digital radiography. Int Endod J. 2007;40:514-20.

Carvalho-Junior JR, Guimarães LF, Correr-Sobrinho L, Pécora JD, Sousa-Neto MD. Evaluation of solubility, desintegration, and dimensional alterations of a glass ionomer root canal sealer. Braz Dent J. 2003;14:114-8.

Case SL, O'Brien EP, Ward TC. Cure profiles, crosslink density, residual stresses, and adhesion in a model epoxy, Polymer, v. 46, n. 24, p. 10831-10840, 2005.

Chang MC, Lin LD, Chen YJ, Tsai YL, Cheng YA, Kuo CS, Chang HH, Tai TF, Lin HJ, Jeng $\mathrm{JH}$. Comparative cytotoxicity of five root canal sealers on cultured human periodontal ligament fibroblasts. Int Endod J. 2010 Mar;43(3):251-7. 
Chang SW, Lee SY, Kang SK, Kum KY, Kim EC. In vitro biocompatibility, inflammatory response, and osteogenic potencial of 4 root canal sealers: Sealapex, Sankin apatite root sealer, MTA Fillapex, and iRoot SP root canal sealer. J Endod. 2014 Oct;40(10):1642-8.

Chávez-Andrade GM, Kuga MC, Duarte MAH, de Toledo Leonardo R, Keine KC, Anna-Junior AS, Só MVR. Evaluation of the Physicochemical Properties and Push-Out Bond Strength of MTA -based Root Canal Cement. J Contemp Dent Pract 2013;14(6):1094-1099.

Cintra LTA, Benetti F, de Azevedo Queiroz ÍO, Ferreira LL, Massunari L, Bueno CRE, de Oliveira SHP, Gomes-Filho JE. Evaluation of the Cytotoxicity and Biocompatibility of New Resin Epoxy-based Endodontic Sealer Containing Calcium Hydroxide. J Endod. 2017 Dec;43(12):2088-2092.

Cohen BI, Pagnillo MK, Musikant BL, Deutsch AS. An in vitro study of the cytotoxicity of two root canal sealers. J Endod. 2000 Apr;26(4):228-9.

Collado-González M, García-Bernal D, Oñate-Sánchez RE, Ortolani-Seltenerich PS, Lozano A, Forner L, Llena C, Rodríguez-Lozano FJ. Biocompatibility of three new calcium silicatebased endodontic sealers on human periodontal ligament stem cells. Int Endod J. 2017; 50:875884.

Consolaro A, Bittencourt G. Leakage of filling materials: is it good or bad? Dental Press Endod. 2014 May-Aug; 4(2):18-25.

Coomaraswamy KS, Lumley PJ, Hofmann MP. Effect of bismuth oxide radiopacifier content on the material properties of an endodontic Portland cement-based (MTA-like) system. J Endod. 2007;33:295-8.

Costa S, Pina C, Coelho P, Costa C, Silva S, Porto B, Laffon B, Teixeira JP. Occupational exposure to formaldehyde: genotoxic risk evaluation by comet assay and micronucleus test using human peripheral lymphocytes. J Toxicol Environ Health A. 2011;74(15-16):1040-51.

Cotti E, Petreucic V, Re D, Simbula G. Cytotoxicity evaluation of a new resin-based hybrid root canal sealer: an in vitro study. J Endod. 2014;40(1):124-8.

Da Silva EJ, Zaia AA, Peters OA. Cytocompatibility of calcium silicate-based sealers in a threedimensional cell culture model. Clin Oral Investig 2017;21:1531-6.

Dammaschke T, Schneider U, Stratmann U, Yoo J-M, SchaÈfer E. Reaction of inflamed periapical tissue to three different root canal sealers. Dtsch ZahnaÈ rztl Z 2006; 61:15-26.

De Almeida WA, Leonardo MR, Tanomaru Filho M, Silva LA. Evaluation of apical sealing of three endodontic sealers. Int Endod J 2000;33:25-7.

Desai S, Chandler N. Calcium hydroxide-based root canal sealers: a review. J Endod. 2009 Apr;35(4):475-80.

Dezan Junior, Eloi. Indução experimental de anacores no periápice de dentes após obturação dos canais: estudo em cães em região geográfica endêmica para Leishmaniose. Tese (doutorado) - Faculdade de Odontologia de Bauru. Universidade de São Paulo - Bauru, 2001. 
Dimitrova-Nakov S, Uzunoglu E, Ardila-Osorio H, Baudry A, Richard G, Kellermann O, et al. In vitro bioactivity of BioRoot ${ }^{\mathrm{TM}} \mathrm{RCS}$, via A4 mouse pulp stem cells. Dent Mater. 2015; 31 : 1290-1297.

Diomede F, Caputi S, Merciaro I et al. Pro-inflammatory cytokine release and cell growth inhibition in primary human oral cells after exposure to endodontic sealer. Internacional Endodontic Journal 2014 47:864-72.

Donnelly A, Sword J, Nishitani Y et al. Water sorption and solubility of methacrylate resinbased root canal sealers. Journal of Endodontics 2007. 33, 990-4.

Duarte MA, Martins CS, de Oliveira Cardoso Demarchi AC, de Godoy LF, Kuga MC,

Eldeniz AU, Mustafa K, Ørstavik D, Dahl JE. Cytotoxicity of new resin-, calcium hydroxideand silicone-based root canal sealers on fibroblasts derived from human gingiva and L929 cell lines. Int Endod J. 2007 May;40(5):329-37.

Eldeniz AU, Shehata M, Högg C, Reichl FX. DNA double-strand breaks caused by new and contemporary endodontic sealers. Int Endod J. 2016 Dec;49(12):1141-1151.

Erausquin J, Muruzábal M. Root canal fillings with zinc oxide-eugenol cement in the rat molar. Oral Surg Oral Med Oral Pathol. 1967 Oct;24(4):547-58.

Ersev H, Schmalz G, Bayirli G, Schweikl H. Cytotoxic and mutagenic potencies of various root canal filling materials in eukaryotic and prokaryotic cells in vitro. J Endod. 1999 May;25(5):359-63.

EU-OSHA - European Agency for Safety and Health at Work. Occupational Safety and Health culture assessment - A review of main approaches and selected tools. 2011.

Evans HJ, O'Riordan ML. Human peripheral blood lymphocytes for the analysis of chromosome aberrations in mutagen tests. Mutat Res. 1975 jun;31(3):135-48.

Freshney RI. Culture of animal cells: a manual of basic technique. $5^{\text {th }}$ ed. New York:WilleyLiss; 2005.

Friedman S, Picca M, Macchi RL, Kaplan AE. Solubility of endodontic sealers in water. Journal of Dental Research, v. 78, n. 5, p. 921, 1991.

Gambarini G, Romeo U, Tucci E, Gerosa R, Nocca G, Lupi A, et al. Cytotoxicity of Epiphany SE endodontic sealer: a comparative in vitro study. Med Sci Monit. 2009;15:PI15-8.

Gandolfi MG, Prati C. MTA and F-doped MTA cements used as sealers with warm guttapercha. Long-term study of sealing ability. International Endodontic Journal 2010. 43:889-901.

Garrido AD, de Cara SP, Marques MM, Sponchiado EC Jr, Garcia Lda F, de Sousa-Neto MD. Cytotoxicity evaluation of copaíba oil-based root canal sealer compared to three commonly used sealers in endodontics. Dent Res J (Isfahan) 2015 Mar-Apr;12(2):121-6.

Gatewood RS. Endodontic materials. Dent Clin North Am. 2007 Jul;51(3):695-712. 
Gerosa R, Menegazzi G, Borin M, Cavalleri G. Cytotoxicity evaluation of six root canal sealers. J Endod. 1995;21:446-448.

Gerosa R, Menegazzi G, Borin M, Cavalleri G. Cytotoxicity evaluation of six root canal sealers. J Endod. 1995;21:446-448.

Geurtsen W, Leyhausen G. Biological aspaects of root canal filling materials-histocomptibility, cytotoxicity and mutagenicity. Clinical Oral Investigations 1997. 1, 5-11.

Goldstein BD. Hematological and toxicological evaluation of formaldehyde as a potential cause of human leukemia. Hum Exp Toxicol. 2011 Jul;30(7):725-35.

Gomes BP, Pedroso JA, Jacinto RC, Vianna ME, Ferraz CC, Zaia AA, de Souza-Filho FJ. In vtiro evaluation of the antimicrobial activity of five root canal sealers. Braz Dent $\mathrm{J}$. 2004;15(1):30-5.

Gomes-Filho JE, Watanabe S, Lodi CS, Cintra LT, Nery MJ, Filho JA, Dezan E Jr, Bernabé PF. Rat tissue reaction to MTA FILLAPEX ${ }^{\circledR}$. Dent Traumatol. 2012 Dec;28(6):452-6.

Guerreiro-Tanomaru JM, Duarte MA, Gonçalves M, Tanomaru-Filho M. Radiopacity evaluation of root canal sealers containing calcium hydroxide and MTA. Braz Oral Res. 2009;23:119-23.

Gulati N, Chandra S, Aggarwal PK, Jaiswal JN, Singh M. Cytotoxicity of eugenol in sealer containing zinc-oxide. Endod Dent Traumatol. 1991 Aug;7(4):181-5.

Hargreaves KM, Cohen S. Caminhos da Polpa. Tradução Alcir Costa Fernandes Filho et al. Rio de Janeiro. Elsevier, 2011. Cap.10.

Hauman CH, Love RM. Biocompatibiliy of dental materials used in comtemporary endodontic therapy: a review. Part 2. Root-canal-filling materials. International Endodontic Journal 2003. $36,147-60$.

Heil J, Reifferscheid G, Waldmann P, Leyhausen G, Geurtsen W. Genotoxicity of dental materials. Mutation Research 1996. 368:181-194.

Ho WY, Yeap SK, Ho CL, Rahim RA, Alitheen NB. Development of multicellular tumor spheroid (MCTS) culture from breast cancer cell and a high throughput screening method using the MTT assay. PLoS One. 2012;7(9).

Ho YC, Huang FM, Chang YC. Cytotoxicity of formaldehyde on human osteoblastic cells is related to intracellular glutathione levels. J Biomed Mater Res B Appl Biomater. 2007 Nov;83(2):340-4.

Holland GR. A histological comparison of periapical inflammatory and neural responses to two endodontic sealers in the ferret. Arch Oral Biol. 1994 Jul;39(7):539-44.

Holland R, de Souza V. Ability of a new calcium hydroxide root canal filling material to induce hard tissue formation. J Endod. 1985 Dec;11(12):535-43.

Huang FM, Chou LS, Chou MY, Chang YC. Protective effect of NAC on formaldehydecontaining-ZOE-based-root-canal-sealers- induced cyclooxygenase-2 expression and 
cytotoxicity in human osteoblastic cells. J Biomed Mater Res B Appl Biomater. 2005 Aug; 7492):768-73.

Huang FM, Tai KW, Chou MY, Chang YC. Cytotoxicity of resin, zinc oxide-eugenol and calcium hydroxide-based root canal sealers on human periodontal ligament cells and permanent V79 cells. Int Endod J. 2002 Feb;35(2):153-8.

Huang T, Lee H, Kao C. Evaluation of the Genotoxicity of Zinc Oxide Eugenol-Based, Calcium Hydroxide-Based, and Epoxy Resin-Based Root Canal Sealers by Comet Assay. J Endod. Dec 2001;27(12):744-8.

Huang TH, Lee H, Kao CT. Evaluation of the genotoxicity of zinc oxide eugenol-based calcium hydroxide-based, and epoxy resin-based root canal sealers by comet assay. J Endod. 2001 Dec;27(12):744-8.

Hume WR. An analysis of the release and the diffusion through dentin of eugenol from zinc oxide-eugenol mixtures. J Dent Res. 1984 Jun;63(6):881-4.

Ingle J, Newton C, West JG. Obturation of the radicular space. In: Ingle J, Bakland L, editors. Endodontics. Hamilton: BC Decker Inc.; 2002. p.571-668.

International Agency of Research on Cancer. Cancer Incidence in Five Continents, Lyon: IARC Scientific Publications. 2006.

International Standard Organization (ISO) 10993-5:2009. Biological compatibility of medical devices - Part 5: Test for cytotoxicity: in vitro methods.

International Standard Organization (ISO) 6876:2012. Dentistry - Root canal sealing materials.

International Standard Organization (ISO) 7405:2008. Dentistry - Evaluation of biocompatibility of medical devices used in dentistry.

ISO 10993-5 - Biological evaluation of medical devices - Part 5: Tests for in vitro cytotoxicity (Third edition). Switzerland, 2009.

Jorge JH, Giampaolo ET, Pavarina AC. Cytotoxicity of the dental materials. A literature review. Rev Odontol UNESP 2004;33(2):65-58.

Jung S, Sielker S, Hanisch MR, Libricht V, SchaÈfer E, Dammaschke T. Cytotoxic effects of four different root canal sealers on human osteoblasts. PLoS ONE. 2018. 13(3):e0194467.

Kaplan AE, Goldberg F, Artaza LP, de Silvio A, Macchi RL. Disintegration of endodontic cements in water. Journal of Endodontics, v. 23, n. 7, p. 439-441, 1997.

Khalil I, Naaman A, Camilleri J. Properties of Tricalcium Silicate Sealers. J Endod. 2016 Oct;42(10):1529-35.

Kim RJ, Shin JH. Cytotoxicity of a novel mineral trioxide aggregate-based root canal sealer. Dent Mater J. 2014;33(3):313-8. 
Koch MJ, Wünstel E, Stein G. Formaldehyde release from ground root canal sealer in vitro. J Endod. 2001 Jun;27(6):396-7.

Konjhodzic-Prcic A, Jakupovic S, Hasic-Brankovic L, Vukovic A. Evaluation of Biocompatibility of Root Canal Sealers on L929 Fibroblasts with Multiscan EX Spectrophotometer. Acta Inform Med. 2015 Jun;23(3):135-7.

Kopper PM, Figueiredo JA, Della Bona A, et al. Comparative in vivo analysis of the sealing ability of three endodontic sealers in post-prepared root canals. Int Endod J 2003;36:857-63.

Lee KW, Williams MC, Camps JJ, Pashley DH. Adhesion of endodontic sealers to dentin and gutta-percha. J Endod. 2002 Oct;28(10):684-8.

Leirskar J, Helgeland K. Mechanism of toxicity of dental materials. Int Endod J. 1981 Jan;14(1):42-7.

Leonardo MR, Bezerra da Silva LA, Filho MT, Santana da Silva R. Release of formaldehyde by 4 endodontic sealers. Oral Surg Oral Med Oral Pathol Oral Radiol Endod. 1999 Aug;88(2):221-5.

Leonardo MR, Silva LA, Utrilla LS, Assed S, Ether SS. Calcium hydroxide root canal sealers - histopathologic evaluation of apical and periapical repair after endodontic treatment. J Endod. 1997 Jul;23(7):428-32.

Lim ES, Park YB, Kwon YS, Shon WJ, Lee KW, Min KS. Physical properties and biocompatibility of an injectable calciumsilicate-based root canal sealer: in vitro and in vivo study. BMC Oral Health 2015 21:129.

Lima NG, Trevizan M, Carvalho FK, Nelson-Filho P, Consolaro A. Can root canal sealers induce cancer? How can we investigate that? Dental Press Endod. 2016 Jan-Apr;6(1):11-4.

Lindgvist L, Otteskog P. Eugenol: liberation from dental materials and effect on human diploid fibroblast cells. Scand J Dent Res. 1980 Dec;88(6):552-6.

Lin-Gibson S, Landis FA, Drzal PL. Combinatorial investigation of the structure-properties characterization of photopolymerized dimethacrylate networks. Biomaterials. 2006 Mar;27(9):1711-7.

Loushine BA, Bryan TE, Looney SW, Gillen BM, Loushine RJ, Weller RN, Pashley DH, Tay FR. Setting properties and cytotoxicity evaluation of a premixed bioceramic root canal sealer. J Endod. 2011 May;37(5):673-7.

Mandal P, Zhao J, Sah SK, Huang Y, Liu J. In vitro cytotoxicity of guttaflow 2 on human gingival fibroblasts. J Endod. 2014 Aug;40(8):1156-9.

Marín-Bauza GA, Rached-Junior FJA, Souza-Gabriel AE, et al. Physicochemical properties of methacrylate resin-based root canal sealers. J Endod 2010;36:1531-6.

Marín-Bauza GA, Silva-Sousa YT, da Cunha SA, Rached-Junior FJ, Bonetti-Filho I, SousaNeto MD, Miranda CE. Physicochemical properties of endodontic sealers of different bases. J Appl Oral Sci. 2012 Jul-Aug;20(4):455-61. 
Mark, HF, Bikales, MN, Overberger, CG, Menges, G. Encyclopedia of polymer science and engineering, Emulsion polymerization to fibers, manufacture, v. 6, John Wiley \& Sons, New York, 1986.

Martins VJ, Lins RX, Berlinck TC, Fidel RA. Cytotoxicity of root canal sealers on endothelial cell culture. Braz Dent J. 2013;24(1):15-20.

McDermott, J. The structure of the advanced composites industry. Advance composites Bluebook, 1990.

McMichen FR, Pearson G, Rahbaran S, Gulabivala K. A comparative study of selected physical properties of five root-canal sealers. Int Endod J. 2003 Sep;36(9):629-35.

McMichen FRS, Pearson G, Rahbaran S, Gulabivala K. A comparative study of selected physical properties of five root-canal sealers. Int Endod J 2003;36:629-35.

Mendonça EF, Estrela C. Reparo após o tratamento endodôntico. In:Estrela C, Figueiredo, JAP. Endodontia: Princípios biológicos e mecânicos, São Paulo: Editora Artes Médicas, 2001; p.295314.

Mestieri LB, Gomes-Cornélio AL, Rodrigues EM, Salles LP, Bosso-Martelo R, GuerreiroTanomaru JM, Tanomaru-Filho M. Biocompatibility and bioactivity of calcium silicate-based endodontic sealers in human dental pulp cells. J Appl Oral Sci. 2015 Oct;23(5):467-71.

Miletić I, Jukić S, Anić I, Zeljezić D, Garaj-Vrhovac V, Osmak M. Examination of cytotoxicity and mutagenicity of AH26 and AH Plus sealers. Int Endod J. 2003 May;36(5):330-5.

Montenegro MR, Facchio D. Inflamações: conceitos gerais e inflamação aguda. In: Montenegro MR, Franco M. Patologia: Processos gerais. 4 ed. São Paulo: Atheneu, 2004. Cap.6, p.109-128.

Mosmann T. Rapid colorimetric assay for cellular growth and survival: application to proliferation and cytotoxicity assays. Journal of Immunologic Methods 1983. 65:55-63.

Nunes VH, Silva RG, Alfredo E, Sousa-Neto MD, Silva-Sousa YTC. Adhesion of Epiphany and AH Plus sealers to human root dentin treated with different solutions. Braz Dent $\mathrm{J}$. 2008;19:46-50.

Opačić-Galić V, Petrović V, Zivković S, Jokanović V, Nikolić B, Knežević-Vukčević J, MitićĆulafić D. New nanostructural biomaterials based on active silicate systems and hydroxyapatite: characterization and genotoxicity in human peripheral blood lymphocytes. Int Endod J. 2013 Jun;46(6):506-16.

Ørstavik D, Nordahl I, Tibballs JE. Dimensional change following setting of root canal sealer materials. Dent Mat. 2001;17:512-9.

Orstavik D. Materials used for root canal obturation: technical, biological and clinical testing. Endod pics. 2005 12:30-41.

Ozorio JEV. Avaliação da quantidade de formaldeído liberado por alguns cimentos endodônticos, 2012 - 157 p. Tese (Doutorado) - Faculdade de Odontologia de Ribeirão Preto, Universidade de São Paulo, Ribeirão Preto, 2012. 
Perassi FT, Filho IB, Berbert FL, Carlos IZ, de Toledo Leonardo R. Secretion of tumor necrosis fator-alpha by mouse peritoneal macrophages in the presence of dental sealers Sealapex and Endomethasone. J Endod. 2004 Jul;30(7):534-7.

Pereira FEL, Bogliolo L. Inflamações. In: Bogliolo et al. Patologia geral. Rio de Janeiro: Guanabara Koogan, 2009. Capt.7, p. 189-205.

Peters OA. Research that matters: biocompatibility and cytotoxicity screening. Int Endod J. 2013;46:195-7.

Pongsavee M. In vitro study of lymphocyte antiptoliferation and cytogenetic effect by occupational formaldehyde exposure. Toxicol Ind Health. 2011 Sep;27(8):719-23.

Preston RJ, San Sebastian JR, McFee AF. The in vitro human lymphocyte assay for assessing the clastogenicity of chemical agents. Mutat Res. 1987 Oct;189(2):175-83.

Prüllage RK, Urban K, Schäfer E, Dammaschke T. Material Properties of a Tricalcium Silicatecontaining, a Mineral Trioxide Aggregate-containing, and an Epoxy Resin-based Root Canal Sealer. J Endod. 2016 Dec;42(12):1784-1788.

Ratanasathien S, Wataha JC, Hanks CT, Dennison JB. Cytotoxicity interactive effects of dentin bonding components om mouse fibroblasts. J Dent Res. 1995 Sep;74(9):1602-6.

Reichl FX, Rothmund L, Shehata M, Högg C. DNA double-strand breaks caused by new and contemporary endodontic sealers. Int Endod J. 2015.

Resende LM, Rached-Junior FJ, Versiani MA, Souza-Gabriel AE, Miranda CE, Silva-Sousa YT, Sousa Neto MD. A comparative study of physicochemical properties of AH Plus, Epiphany, and Epiphany SE root canal sealers. Int Endod J. 2009 Sep;42(9):785-93.

Ricucci D, Rôças IN, Alves FR, Loghin S, Siqueira JF Jr. Apically extruded sealers: Fate and influence on treatment outcome. J Endod. 2016 Feb;42(2):243-9.

Rodríguez-Lozano FJ, García-Bernal D, Oñate-Sánchez RE, Ortolani-Seltenerich PS, Forner L, Moraleda JM. Evaluation of cytocompatibility of calcium silicate-based endodontic sealers and their effects on the biological responses of mesenchymal dental stem cells. Int Endod J. 2017 Jan;50(1):67-76.

Rodríguez-Lozano FJ, García-Bernal D, Ros-Roca Mde L, Algueró Mdel C, Oñate-Sánchez RE, Camacho-Alonso F, Moraleda JM. Cytoprotective effects of melatonin on zoledronic acidtreated human mesenchymal stem cells in vitro. J Craniomaxillofac Surg. 2015 Jul;43(6):85562.

Ruparel NB, Chen PB, Ishikawa B, Diogenes A. Direct effect of endodontic sealers on trigeminal neuronal acitivity. J Endod. 2014;40(5):683-7.

Savioli, RN. Avaliação das propriedades físico-químicas de alguns tipos de cimentos endodônticos à base de óxido de zinco-eugenol. Tese (Doutorado). USP - São Paulo. 1998. $62 \mathrm{p}$.

Scelza MZ, Coil J, Alves GG. Effect of time of extraction on the biocompatibility of endodontic sealers with primary human fibroblasts. Braz Oral Res. 2012 Sep-Oct;26(5):424-30. 
Schäfer E, Bering N, B€urklein S. Selected physicochemical properties of AH-Plus, EndoREZ and RealSeal SE root canal sealers. Odontology 2015;103:61-5.

Schafer E, Zandbiglari T. Solubility of root-canal sealers in water and artificial saliva. International Endodontic Journal 2003. 36, 660-9.

Schmalz G. Use of cell cultures for toxicity testing of dental materials-advantages and limitations. J Dent. 1994; 22 Suppl 2:S6-11.

Schwarze T, Fiedler I, Leyhausen G, Geurtsen W. The cellular compatibility of five endodontic sealers during the setting period. J Endod. 2002;28:784-786.

Seltzer S. Pain in Endodontics. J Endod. 2004; 30(7):501-3.

Seymour RA, Walton JG. Pain control after third molar surgery. Int J Oral Surg. 1984 Dec;13(6):457-85.

Siboni F, Taddei P, Zamparini F, Prati C, Gandolfi MG. Properties of BioRoot RCS, a tricalcium silicate endodontic sealer modified with povidone and polycarboxylate. Int Endod J. 2017 Dec;50 Suppl 2:e120-e136.

Silva EJ, Rosa TP, Herrera DR, Jacinto RC, Gomes BP, Zaia AA. Evaluation of cytotoxicity and physicochemical properties of calcium silicate-based endodontic sealer MTA Fillapex. J Endod. 2013 39:274-277

Silva EJ, Santos CC, Zaia AA. Long-term cytotoxic effects of contemporary root canal sealers. J Appl Oral Sci. 2013 Jan-Feb;21(1):43-7.

Silva GO, Cavalcanti BN, Oliveira TR, Bin CV, Camargo SE, Camargo CH. Cytotoxicity and genotoxicity of natural resin-based experimental endodontic sealers. Clin Oral Investig. 2016 May;20(4):815-9.

Silva LAB, Azevedo LU, Consolaro A, Barnett F, Xu Y, Battaglino RA, Cañadas PS, de Oliveira KMH, Silva RAB. Novel endodontic sealers induce cell cytotoxicity and apoptosis in a dose-dependent behavior and favorable response in mice subcutaneous tissue. Clin Oral Investig. 2017 Dec;21(9):2851-2861.

Silva LAB. Silva, L.A.B. Protocolos Clínicos - Tratamento Endodôntico de Dentes Decíduos. 1. ed., 2015. v. 1. 145 p.

Sipert CR, Hussne RP, Nishiyama CK, Torres SA. In vitro antimicrobial activity of Fill Canal, Sealapex, Mineral Trioxide Aggregate, Portland cement and EndoRez. Int Endod J. 2005 Aug;38(8):539-43.

Siqueira JF Jr. Strategies to treat infected root canals. J Calif Dent Assoc. 2001 Dec;29(12):82537.

Sousa-Neto MD, Guimarães LF, Gariba Silva R, Saquy PC, Pécora JD. The influence of different grades of rosins and hydrogenated resins on the powder-liquid ratio of Grossman cements. Braz Dent J. 1998;9:11-8. 
Sousa-Neto MD, Guimarães LF, Saquy PC, Pécora JD. Effect of different grades of gum rosins and hydrogenated resins on the solubility, disintegration, and dimensional alterations of Grossman cement. J Endod. 1999 Jul;25(7):477-80.

Spagnuolo G, D'Anto V, Valletta R et al. Effect of 2-hydroxyethyl methacrylate on human pulp cell survival pathways ERK and AKT. Journal of Endodontics 2008. 34, 684-8.

Spangberg L, Pascon EA. The importance of material preparation for the expression. Of cytotoxicity during in vitro evaluation of biomaterials. J Endod. 1988 May;14(5):247-50.

Spangberg LS, Barbosa SV, Lavigne GD. AH 26 releases formaldehyde. J Endod. 1993 Dec;19(12):596-8. Stoddart M. Mammalian Cell Viability. 1 ed. Humana Press, 2011. p.740.

Tai KW, Huang FM, Huang MS, Chang YC. Assesment of the genotoxicity of resin and zincoxide eugenol-based root canal sealer using an in vitro mammalian test system. J Biomed Mater Res. 2002 Jan;59(1):73-7.

Takahashi K, Sawasaki Y, Hata J, Mukai K, Goto T. Spontaneous transformationand immortalization of human endothelial cells. In Vitro Cell Dev Biol. 1990 Mar;26(3 Pt 1):26574.

Tanomaru Filho M, Leonardo MR, Silva LA, Utrilla LS. Effect of diferente root canal sealers on periapical repair of teeth with chronic periradicular periodontitis. International Endodontic Journal 1998. 31,85-9.

Tanomaru-Filho M, da SILVA, GF, Duarte, M.A, Gonçalves, M, Tanomaru, JM. Radiopacity evaluation of root-end filling materials by digitization of images. Journal of Endodontic, v. 33, n. 3, p. 249-251, 2007.

Teixeira L, Basso FG, Hebling J, Costa CAS, Mori GG, Silva-Sousa YTC, Oliveira CF. Cytotoxicity Evaluation of Root Canal Sealers Using an In Vitro Experimental Model with Roots. Braz Dent J. 2017 Mar-Apr;28(2):165-171.

Tepel J, Darwisch el Sawaf M, Hoppe W. Reaction of inflamed periapical tissue to intracanal medicaments and root canal sealers. Endodontics and Dental Traumatology 1994. 10, 233-8.

Van Landuyt KL, Geebelen B, Shehata M, Furche SL, Durner J, Van Meerbeek B, Hickel R, Reichl FX. No Evidence for DNA Double-strand Breaks Caused by Endodontic Sealers. J Endod May 2012;38(5)636-41

Versiani MA, Carvalho-Júnior JR, Padilha MI, Lacey S, Pascon EA, Sousa-Neto MD. A comparative study of physicochemical properties of AH Plus and Epiphany root canal sealants. Int Endod J. 2006;39:464-71.

Viapiana R, Guerreiro-Tanomaru JM, Hungaro-Duarte MA, Tanomaru-Filho M, Camilleri J. Chemical characterization and bioactivity of epoxy resin and Portland cement-based sealers with niobium and zirconium oxide radiopacifiers. Dent Mater. 2014 Sep;30(9):1005-20.

Vidal KAL. Estudo da citotoxicidade de três cimentos obturadores de canais endodônticos à base de óxido de zinco e eugenol em cultura celular L929. Duque de Caxias, 2007. 97p. Dissertação (mestrado) - Universidade do Grande Rio "Prof. José de Souza Herdy" - Duque de Caxias, Rio de Janeiro. 
Whitworth J. Methods of filling root canals: principles and practices. Endod Topics 2005;12:224.

Willershauesen I, Wolf T, Kasaj A, Weyer V, Willershauesen B, Marroquin BB. Influence of a bioceramic root end material and minaeral trioxide aggregates on fibroblasts and osteoblasts. Archives of Oral Biology 2013. 58:1232-7.

Willershausen I, Callaway A, Briseño B, Willershause B. In vitro analysis of the cytotoxicity and the antimicrobial effect of four endodontic sealers. Head and Face Med. 2011 Aug 10;7:15.

Willersshausen I, Wolf T, Kasaj A, Weyer V, Willershausen B, Marroquin BB. Influence of a bioceramic root end material anda mineral trioxide aggregates on fibroblasts and osteoblasts. Archives of Oral Biology 2013 58:1232-7.

Wilson AD, McLean JW. Glass ionomer cements. Chicago, Quintessence, 1988.

Wu MK, Dummer PM, Wesselink PR. Consequences of and strategies to deal with residual post-treatment root canal infection. Int Endod J. 2006 May;39(5):343-56.

Wyatt MD, Pittman DL. Methylating agens and DNA repair responses: Methylate bases and sources of strand breaks. Chem Res Toxicol. 2006 Dec;19(12):1580-94.

Yamashita JC. Calcium and hydroxide release from different pulp-capping materials. Oral Surg Oral Med Oral Pathol Oral Radiol Endod. 2007 Jul;104(1):e66-9.

Yoshimine Y, Yamamoto M, Ogasawara T, Koishi Y, Tanabe K, Hashiguchi I, et al. In vitro evaluation of the cytocompatibility of a glass-ionomer cemente sealer. J Endod. 2003;29:4535.

Yoshino P, Nishiyama CK, Modena KC, Santos CF, Sipert Cr. In vitro cytotoxicity of White MTA, MTA Fillape ${ }^{\circledR}$ and Portland cement on human periodontal ligament fibroblasts. Brazilian Dental Journal 2013 24:111-6.

Zhang H, Pappen FG, Haapasalo M. Dentin enhances the antibacterial effect of mineral trioxide aggregate and bioaggregate. J Endod. 2009 Feb;35(2):221-4.

Zhang H, Shen Y, Ruse ND, Haapasalo M. Antibacterial activity of endodontic sealers by modified direct contact test against Enterococcus faecalis. J Endod 2009;35:1051-5.

Zhang W, Li Z, Peng B. Assessment of a new root canal sealer's apical sealing ability. Oral Surg Oral Med Oral Pathol Oral Radiol Endod 2009;107:e79-82.

Zhou HM, TF D, Shen Y, Wang ZJ, Zheng YF, Haapasalo M. In vitro cytotoxicity of calcium silicate-containing endodontic sealers. J Endod. 2015 41:56-61

Zmener O, Banegas G, Pameïjer CH. Bone tissue response to a methacrylate-based endodontic sealer: a histological and histometric study. J Endod. 2005; 31:457-549.

Zoufan K, Jiang J, Komabayashi T, Wang YH, Safavi KE, Zhu Q. Cytotoxic evaluation of Gutta Flow and EndoSequence BC sealers. Oral Surg Oral Med Oral Pathol Oral Radiol Endod. 2011 Nov;112(5):657-61. 
Zoufan K, Jiang J, Komabayashi T, Wang YH, Safavi KE, Zhu Q. Cytotoxicity evaluation of Gutta Flow and Endo Sequence BC sealers. Oral Surg Oral Med Oral Pathol Oral Radiol Endod. 2011 Nov;112(5):657-61.

Zoufan K, Jiang J, Komabayashi T, Wang YH, Safavi KE, Zhu Q. Cytotoxicity evaluation of Gutta Flow and Endo Sequence BC sealers. Oral Surg Oral Med Oral Pathol Oral Radiol Endod. 2011 Nov;112(5):657-61. 

Anexas 

ANEXO A - Parecer do comitê de ética

\section{FACULDADE DE \\ ODONTOLOGIA DE RIBEIRÃO PRETO/ FORP/ USP}

\section{PARECER CONSUBSTANCIADO DO CEP}

\section{DADOS DO PROJETO DE PESQUISA}

Título da Pesquisa: Avaliação do potencial mutagênico de substâncias utilizadas na endodontia Pesquisador: Nicole Gonçalves Lima

Área Temática:

Versão: 3

CAAE: 41659915.2 .0000 .5419

Instituição Proponente: Universidade de Sao Paulo

Patrocinador Principal: Financiamento Próprio

DADOS DO PARECER

Número do Parecer: 1.126.236

Data da Relatoria: 24/06/2015

Apresentação do Projeto:

Os pesquisadores adequaram a área temática do projeto, única questão que o CEP da FORP solicitou correção.

Objetivo da Pesquisa:

Os mesmos descritos inicialmente.

Avaliação dos Riscos e Benefícios:

Os mesmos descritos inicialmnete.

Comentários e Considerações sobre a Pesquisa:

Adequação solicitada foi executada.

Considerações sobre os Termos de apresentação obrigatória:

Adequado.

Recomendaçöes:

Aprovado.

Conclusões ou Pendências e Lista de Inadequações:

Aprovado.

Situação do Parecer:

Aprovado

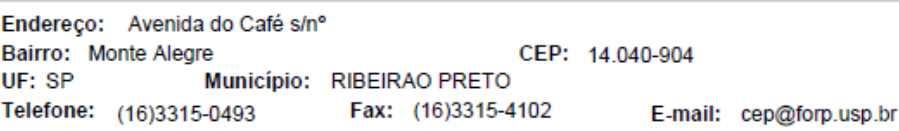


$92 \mid$ A n exos

\section{FACULDADE DE \\ ODONTOLOGIA DE RIBEIRÃO \\ PRETO/ FORP/ USP Plataforma
Brasil}

Continuação do Parecer: 1.126.236

Necessita Apreciação da CONEP:

Não

Considerações Finais a critério do CEP:

Conforme deliberado na $181^{\text {a }}$ Sessão Ordinária do CEP, realizada em 25/06/2015.

RIBEIRAO PRETO, 26 de Junho de 2015

Assinado por:
Simone Cecilio Hallak Regalo

Simone Cecilio Hallak
(Coordenador)

Endereço: Avenida do Café $s / n^{\circ}$

Bairro: Monte Alegre

CEP: $14.040-904$

UF: SP Município: RIBEIRAO PRETO

Telefone: (16)3315-0493 Fax: (16)3315-4102

E-mail: cep@forp.usp.br 
ANEXO B - Termo de consentimento livre e esclarecido

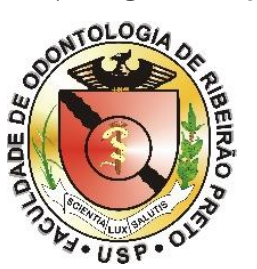

\section{UNIVERSIDADE DE SÃO PAULO FACULDADE DE ODONTOLOGIA DE RIBEIRÃO PRETO}

\section{TERMO DE CONSENTIMENTO LIVRE E ESCLARECIDO}

Convidamos você a participar de um projeto de pesquisa que será desenvolvido no Laboratório de Nutrigenômica da Faculdade de Ciências Farmacêuticas de Ribeirão Preto da Universidade de São Paulo. O título do projeto é "Avaliação da genotoxicidade de materiais utilizados para obturação de canais radiculares de dentes decíduos e permanentes". Os responsáveis pela pesquisa são os Profa. Dra. Lusânia Maria Greggi, Prof. Dr. Fabricio Kitazono de Carvalho e também sua orientada Fernanda Vicioni Marques, que será a responsável pela apresentação e obtenção do Termo de Consentimento Livre e Esclarecido. A justificativa para a realização da pesquisa é que durante o processo de obturação dos canais radiculares, é comum haver extravasamento do material obturador, o qual ficar em contato direto com os tecidos periapicais (tecido que recobre a raiz do elemento dentário). Estudos mostram que esses materiais em contato direto com o tecido causam uma resposta inflamatória. Porém, até o presente momento, somente alguns estudos avaliaram a genotoxicidade de substâncias presentes nos materiais utilizados em endodontia. Diante disso, o presente projeto avaliará a genotoxicidade de diferentes materiais indicados para procedimentos endodônticos conservadores e radicais, tanto de dentes decíduos, quando de permanentes. O sujeito da pesquisa não terá qualquer contato com o composto testado, pois todo o tratamento será realizado no sangue retirado do voluntário.

Os prováveis benefícios do estudo será o melhor conhecimento dos materiais endodônticos a fim de auxiliar o cirurgião-dentista a fazer a escolha dos materiais odontológicos com melhores propriedades biológicas, e que não traga danos à saúde do paciente.

Informamos que a sua participação será voluntária, e que você não receberá pagamento para participar da pesquisa. Você poderá retirar o seu consentimento e desistir de participar da pesquisa, sem qualquer prejuízo. Uma vez que seu consentimento for retirado antes da publicação dos resultados, os dados referentes à sua amostra de sangue serão retirados dos resultados finais. Garantimos que a sua intimidade e privacidade não serão divulgadas, as informações serão secretas e os dados da pesquisa, que serão apresentados em trabalhos e eventos científicos, não informarão o seu nome ou suas iniciais. Garantimos também que este termo será elaborado em duas vias, sendo que você receberá uma das vias do Termo de Consentimento Livre e Esclarecido após as assinaturas. Se concordar em participar da pesquisa você não entrará em contato direto com os materiais testados. Você será submetido a uma colheita de $10 \mathrm{~mL}$ de sangue (única vez), com seringa e agulhas descartáveis, realizada por profissional da área da saúde e com experiência em exames de sangue, a coleta será realizada na Faculdade de Ciências Farmacêuticas da Universidade de São Paulo (FCFRP), em sala reservada, mantendo as barreiras de biossegurança necessárias, como uso de luvas de procedimento descartáveis, assepsia do local antes da punção. $\mathrm{O}$ material colhido será armazenado em tubos de ensaio estéreis. Os riscos são mínimos, com o desconforto de uma punção venosa, sendo que a formação de hematoma seria a complicação mais frequente da punção venosa periférica. As amostras de sangue deste trabalho serão utilizadas somente para esta pesquisa, ficarão sob a guarda dos pesquisadores e não serão armazenadas, sendo descartadas após a realização dos testes de acordo com as boas práticas de laboratório.

Caso precise de mais esclarecimentos ou sinta necessidade de conversar com os pesquisadores, você poderá fazê-lo pelos telefones abaixo. Inclusive, poderá entrar em contato com o Comitê de Ética da Faculdade de Odontologia de Ribeirão Preto (USP), no endereço Avenida do Café S/№ - Monte Alegre - CEP 14040-903 - Ribeirão Preto - SP. Secretaria do CEP/FORP/USP pelo telefone (16) 3315-0493, Email: cep@forp.usp.br nos horários das 8h às 12h, de segunda à sexta-feira (exceto feriados e pontos facultativos). 
$\mathrm{Eu}$,

R.G. $n^{\circ}$ : abaixo assinado, tendo sido devidamente esclarecido sobre o projeto de pesquisa intitulado "Avaliação da genotoxicidade de materiais utilizados para obturação de canais radiculares de dentes decíduos e permanentes", especialmente no que diz respeito ao objetivo da pesquisa, aos procedimentos a que serei submetido, aos riscos e aos benefícios, declaro que tenho pleno conhecimento dos direitos e das condições que me foram assegurados. Declaro, ainda, que concordo inteiramente com as condições que me foram apresentadas e que, livremente, manifesto a minha vontade em participar do referido projeto.

Sujeito de pesquisa

Pesquisador Responsável

P.G. Fernanda Vicioni Marques

CPF 230.307.248-40

Fone: (16) 99993-6791

Pesquisador Participante

Profa. Dra. Lusânia Maria Greggi Antunes

CPF 180.988.908-13

Fone: (16) 3602-4186

Celular: (16) 8116-7506

Pesquisador Participante

Prof. Dr. Fabricio Kitazono de Carvalho

CPF 219.486.118-13

Fone: (16) 3315-4116 